\title{
Habilitacje w Polsce Ludowej. Część 2. Warunki i przebieg habilitacji w prawie o stopniach i tytułach naukowych
}

\section{Wprowadzenie}

Począwszy od odzyskania przez Polskę niepodległości, prawo habilitowania wprowadzono na mocy wydanej w 1920 r. pierwszej ustawy o szkołach akademickich ${ }^{1}$. Prawo to z pewnymi zmianami zachowano nie tylko w kolejnej w okresie Polski międzywojennej ustawie o szkołach akademickich (z 1933 r. $^{2}$ ), ale także w przepisach prawnych z pierwszych lat Polski Ludowej (1945-1951³). Aktami tymi nie wiązano habilitacji z nadaniem stopnia naukowego. Istotne zmiany w tym zakresie wprowadzono dopiero ustawą z 1958 r. ${ }^{4}$ Co więcej, podczas jej obowiązywania, począwszy od kwietnia 1965 r., wyłączono prawną regulację habilitacji z ustawodawstwa szkolnictwa wyższego ${ }^{5}$. Jej unormowanie poddano odrębnej ustawie - o stopniach naukowych i tytułach naukowych ${ }^{6}$. Nie oznaczało to wyłączenia wpływu ministra

${ }^{1}$ Ustawa z dnia 13 VII 1920 r. o szkołach akademickich (Dz.U. RP Nr 72, poz. 494 ze zm.).

${ }^{2}$ Ustawa z dnia 15 III 1933 r. o szkołach akademickich (tekst jedn. Dz.U. RP 1938 Nr 1, poz. 6 ze zm.).

${ }^{3}$ Dekret z dnia 28 X 1947 r. o organizacji nauki i szkolnictwa wyższego (Dz.U. Nr 66, poz. 415).

${ }^{4}$ Ustawa z dnia 5 XI 1958 r. o szkołach wyższych (Dz.U. Nr 68, poz. 336 ze zm.).

${ }^{5} \mathrm{O}$ habilitacjach normowanych prawem szkolnictwa wyższego zob. K. Wojtczak, Habilitacje w Polsce Ludowej. Część 1. Warunki i przebieg habitacji w prawie szkół wyższych, "Studia Prawa Publicznego" 2017, nr 1 (17), s. 25.

${ }^{6}$ Ustawa z dnia 31 III 1965 r. o stopniach naukowych i tytułach naukowych (Dz.U. Nr 14, poz. 101 ze zm.). Ustawa ta weszła w życie z dniem 9 IV 1965 r. 
szkolnictwa wyższego (także innego ministra nadzorującego szkołę wyższą) od spraw dotyczących przewodów habilitacyjnych i nadawania stopni naukowych. Taką stabilnością nie cechowały się rozwiązania włączające w proces habilitowania Radę Główną Szkolnictwa Wyższego oraz Centralną Komisję Kwalifikacyjną. W ślad za ustawą z 1958 r. o szkołach wyższych ustawa z 1965 r. tę pierwszą (Radę Główną) jako organ doradczy i opiniodawczy ministra zachowała do 1973 r. Do niej, już jako Rady Głównej Nauki i Szkolnictwa Wyższego z zawężonym zakresem kompetencji, powróciła w 1985 r. ${ }^{7}$ Instytucję drugą przywrócono $^{8}$ z kolei w 1973 r. pod zmienioną nieco nazwą - Centralna Komisja Kwalifikacyjna do Spraw Kadr Naukowych (CKK), przy zachowaniu jej podporządkowania Prezydium Rządu.

Wprowadzenie w 1965 r. ustawy o stopniach naukowych i tytułach naukowych miało znaczenie niebagatelne. Przede wszystkich zapoczątkowało proces oddzielenia prawnej regulacji spraw kształcenia studentów od prawa do rozwoju naukowego ${ }^{9}$ kadry kształcącej i naukowej. Nie było to prawo w pełni stabilne. Do czasu wprowadzenia w 1990 r., już w III Rzeczypospolitej, nowego aktu10, ustawa z 1965 r. była ośmiokrotnie zmieniana. Nowelizacjom podlegały także wydane na jej podstawie przepisy wykonawcze. To, co było w ówczesnych zmianach najważniejsze i co jest przedmiotem rozważań tej części opracowania, bez wątpienia dotyczy: (1) zastąpienia dawniejszych gałęzi nauki dziedziną nauki lub dyscypliną naukową będącą przedmiotem przewodu habilitacyjnego; (2) nowego uregulowania wymagań determinujących prawo jednostek (placówek) w zakresie nadawania stopnia naukowego - docenta/doktora habilitowanego; (3) objęcia ich wykazami ustalanymi wyłącznie przez właściwego ministra bądź w porozumieniu z nim; (4) warunków przebiegu przewodu habilitacyjnego; (5) nadawania stopni naukowych przy określeniu środków ochrony prawnej od rozstrzygnięć rad (wydziału, naukowych) w tym zakresie.

${ }^{7}$ Kadencja Rady Głównej wygasła z dniem 31 XII 1990 r. Zob. art. 183 ust. 3 Ustawy z dnia 12 IX 1990 r. o szkolnictwie wyższym (Dz.U. Nr 65, poz. 385).

${ }^{8}$ Instytucję Centralnej Komisji Kwalifikacyjnej do Spraw Pracowników Naukowych i jej skład osobowy ukonstytuowano art. 50 Ustawy z dnia 15 XII 1951 r. o szkolnictwie wyższym i o pracownikach nauki (Dz.U. 1952 Nr 6, poz. 38).

${ }^{9}$ Sprawy awansu zawodowego kadry kształcacej i naukowej pozostawiono uregulowaniu ustawami o szkolnictwie wyższym.

${ }^{10}$ Chodzi tu o Ustawę z dnia 12 IX 1990 r. o tytule naukowym i stopniach naukowych (Dz.U. Nr 65, poz. 386). 
Wbrew oczekiwaniom przed rokiem 1965 nie każda jednostka organizacyjna szkoły wyższej mogła przeprowadzać przewody habilitacyjne. Nie każdą z nich objęto wykazami uprawniającymi do nadawania stopni naukowych. Wykazami powszechnie publikowanymi nie objęto placówek naukowych Polskiej Akademii Nauk (PAN) oraz instytutów naukowych. Ten stan rzeczy zmienił się dopiero po $1965 \mathrm{r}$.

\section{Uprawnienia do habilitowania}

W ślad za ustawą z 1958 r. prawo nadawania stopni naukowych mogły nabyć: szkoły wyższe, placówki naukowe PAN oraz instytuty naukowo-badawcze. Po 1965 r. mogły je w ramach szkół wyższych (poza wydziałami i innymi ich jednostkami organizacyjnymi) uzyskać także samodzielne placówki szkół wyższych typu naukowo-dydaktycznego ${ }^{11}$. Ten zakres podmiotowy do $1990 \mathrm{r}$. ulegał pewnym zmianom. Od $1973 \mathrm{r}$. rozszerzono go o jednostki organizacyjne niebędące instytutami, lecz prowadzące prace naukowo-badawcze (tzw. jednostki typu naukowo-badawczego $)^{12}$. Od tego rozwiązania w 1985 r. odstąpiono ${ }^{13}$. Nadawanie stopnia naukowego docenta (od $1968 \mathrm{r} .{ }^{14}$ doktora habilitowanego) leżało w gestii odpowiednio rad wydziałowych (w szkołach wyższych) oraz rad naukowych (w placówkach naukowych PAN, instytutach naukowo-badawczych, samodzielnych placówkach typu naukowo-dydaktycznego).

${ }^{11}$ Przepisy dotyczące nadawania stopni naukowych w szkołach wyższych i w instytutach naukowo-badawczych stosowano odpowiednio do nadawania stopni naukowych $\mathrm{w}$ akademiach wojskowych i w wojskowych instytutach naukowo-badawczych, z zastrzeżeniami przyjętymi art. 15 ustawy. Zob. też Ustawę z dnia 31 III 1965 r. o wyższym szkolnictwie wojskowym (Dz.U. Nr 11, poz. 102).

${ }_{12}$ Zob. art. 1 pkt 1) Ustawy z dnia 12 IV 1973 r. o zmianie przepisów dotyczących stopni naukowych i tytułów naukowych oraz organizacji instytutów naukowo-badawczych (Dz.U. Nr 12, poz. 89).

${ }^{13}$ Artykuł 1 pkt 1) Ustawy z dnia 25 VII 1985 r. o zmianie ustawy o stopniach naukowych i tytułach naukowych (Dz.U. Nr 36, poz. 168).

${ }^{14} \mathrm{~W} 1968 \mathrm{r}$. stanowisko naukowe docenta zastąpiono stopniem naukowym doktora habilitowanego. Zob. art. 1 pkt 5 Ustawy z dnia 20 XII 1968 r. o zmianie ustawy o stopniach naukowych i tytułach naukowych (Dz.U. Nr 46, poz. 335) oraz § 1 Zarządzenia Ministra Oświaty i Szkolnictwa Wyższego z dnia 8 IV 1969 r. zmieniające zarządzenie w sprawie bliższego określenia stopni naukowych i tytułów naukowych w zależności od dziedziny nauki lub dyscypliny naukowej, których te stopnie i tytuły dotyczą (M.P. Nr 16, poz. 130). 
Generalnie zakreślony zakres podmiotowy nie oznaczał prawa każdej z tych instytucji do nadawania stopni naukowych i przeprowadzania przewodów habilitacyjnych. Tylko te bowiem $z$ nich mogły je nadawać i przewody przeprowadzać, które (1) w zakresie danej dziedziny nauki lub dyscypliny naukowej tworzyły (2) środowisko naukowe o odpowiednio wysokim poziomie i były (3) objęte wykazem jednostek uprawnionych do nadawania stopnia naukowego.

\subsection{Stopnie naukowe a dziedziny nauki}

Z mocy ustawy z 1965 r. minister szkolnictwa wyższego w porozumieniu z sekretarzem naukowym PAN miał ustalić bliższe określenie stopni naukowych $\mathbf{w}$ zależności od dziedziny nauki lub dyscypliny naukowej, których one dotyczą. I tę delegację minister częściowo wypełnił. Zarządzeniem z dnia 15 lipca 1965 r. ${ }^{15}$ wskazał szesnaście dziedzin nauki, $\mathrm{w}$ jakich stopień naukowy docenta mógł być nadawany (chemiczne, ekonomiczne, farmaceutyczne, fizyczne, humanistyczne, leśne, matematyczne, medyczne, prawne, przyrodnicze, rolnicze, techniczne, weterynaryjne, wojskowe, wychowania fizycznego i teologiczne). Zarazem zarządzeniem tym zobowiązał uprawnione rady (wydziału, naukową) do uzupełniania stopnia docenta bliższym określeniem (np. nauk chemicznych) przez podanie zakresu specjalności odpowiadającej przedmiotowi przewodu habilitacyjnego. Listę tę w 1970 r. ${ }^{16}$, już dla stopnia naukowego doktora habilitowanego, rozszerzono o dwie kolejne dziedziny nauk: geograficzne i polityczne, a dwa lata później (1972 r.) kolejnym zarządzeniem ${ }^{17}$ o dziedzinę nauk towaroznawczych. Zarządzeniem zmieniającym w 1974 r. ${ }^{18}$ listą objęto także nauki o organizacji

${ }^{15}$ M.P. Nr 38, poz. 218.

${ }^{16}$ Zarządzenie Ministra Oświaty i Szkolnictwa Wyższego z dnia 2 II 1970 r. zmieniające zarządzenie w sprawie bliższego określenia stopni naukowych i tytułów naukowych w zależności od dziedziny nauki lub dyscypliny naukowej, których te stopnie i tytuły dotyczą (M.P. Nr 5, poz. 44).

${ }_{17}$ Zarządzenie Ministra Nauki, Szkolnictwa Wyższego i Techniki z dnia 30 VIII 1972 r. w sprawie bliższego określenia stopni naukowych i tytułów naukowych w zależności od dziedziny nauki lub dyscypliny naukowej, których te stopnie i tytuły dotyczą (M.P. $\mathrm{Nr}$ 44, poz. 234). Wzorem zarządzenia z 1965 r. zarządzeniem tym także zobowiązano rady (wydziałowe, naukowe) do wskazania zakresu specjalności odpowiadającej przedmiotowi przewodu habilitacyjnego.

${ }_{18}$ Zarządzenie Ministra Nauki, Szkolnictwa Wyższego i Techniki z dnia 16 VII 1974 r. zmieniające zarządzenie w sprawie bliższego określenia stopni naukowych i tytułów 
i zarządzaniu. I w tym kształcie lista ta, pozwalająca bliżej określić stopień naukowy doktora habilitowanego w jednej z dwudziestu nauk, nie zmieniła się do czasu wydania nowego zarządzenia w $1986 \mathrm{r}^{19} \mathrm{Za}^{1}$ rządzenie to zmieniło filozofię dotąd przyjętą. Po raz pierwszy określało dziedziny nauki oraz dla większości z nich dyscypliny naukowe, w zakresie których mogły być nadawane stopnie naukowe doktora habilitowanego. Wykazem objęto jedynie szesnaście dziedzin nauk (chemiczne, ekonomiczne, farmaceutyczne, fizyczne, humanistyczne, leśne, matematyczne, medyczne, kultury fizycznej, prawne, przyrodnicze, rolnicze, techniczne, weterynaryjne, wojskowe, teologiczne). Dla sześciu z nich (farmaceutycznych, leśnych, kultury fizycznej, weterynaryjnych, wojskowych, teologicznych) nie określono dyscyplin naukowych. Dla pozostałych dziedzin nauki liczba im przyporządkowanych dyscyplin naukowych była różna (od dwóch do dwudziestu) ${ }^{20}$. Zarządzeniem tym zachowano nałożony na rady (wydziałów, naukowe) wcześniejszymi zarządzeniami (z 1965 i 1972 r.) obowiązek dookreślenia stopnia doktora habilitowanego określonych nauk przez wskazanie zakresu specjalności

naukowych w zależności od dziedziny nauki lub dyscypliny naukowej, których te stopnie i tytuły dotyczą (M.P. Nr 27, poz. 161).

${ }^{19}$ Zarządzenie Ministra Nauki i Szkolnictwa Wyższego z dnia 18 VI 1986 r. w sprawie dziedzin nauki i dyscyplin naukowych, w zakresie których mogą być nadawane stopnie naukowe, oraz bliższego określenia stopni naukowych i tytułów naukowych (M.P. Nr 18, poz. 125). Zarządzenie to wraz ze zmianami uchylono z dniem 31 III $1991 \mathrm{r}$.

${ }^{20}$ Przyporządkowanie dyscyplin naukowych, podanych w nawiasie, dziedzinom nauk wyglądało następująco: nauki chemiczne (chemia fizyczna i teoretyczna, chemia nieorganiczna, chemia organiczna); nauki ekonomiczne (ekonomia, organizacja i zarządzanie, towaroznawstwo); nauki fizyczne (astronomia, fizyka); nauki humanistyczne (archeologia, bibliotekoznawstwo i informacja naukowo-techniczna, filozofia i socjologia, historia, językoznawstwo, literaturoznawstwo, nauka o polityce, pedagogika, psychologia); nauki matematyczne (informatyka, matematyka); nauki medyczne (biologia medyczna, medycyna, pielęgniarstwo, stomatologia); nauki prawne (nauka o administracji, prawo, prawo kanoniczne); nauki przyrodnicze (biologia, geofizyka, geografia, geologia, oceanologia); nauki rolnicze (agrotechnika, melioracje wodne, ogrodnictwo, rybactwo, technika rolnicza, technologia żywności, zootechnika); nauki techniczne (architektura i urbanistyka, automatyka i robotyka, biocybernetyka i inżynieria biomedyczna, budowa i eksploatacja maszyn, budownictwo, elektronika, elektrotechnika, geodezja i kartografia, górnictwo i geologia inżynierska, informatyka, inżynieria chemiczna, inżynieria, materiałowa, inżynieria środowiska, mechanika, metalurgia, techniki nawigacji, technologia chemiczna, technologia drewna, telekomunikacja, transport). Mocą zarządzenia z 1989 r. dziedzinę nauk technicznych rozszerzono o dyscyplinę naukową - włókiennictwo, zob. Zarządzenie Ministra Edukacji Narodowej z dnia 10 IV 1989 r. zmieniające zarządzenie w sprawie dziedzin nauki i dyscyplin naukowych, w zakresie których mogą być nadawane stopnie naukowe, oraz bliższego określenia stopni naukowych i tytułów naukowych (M.P. Nr 12, poz. 98). 
odpowiadającej przedmiotowi przewodu habilitacyjnego, a także dodano rozwiązanie nowe. Rada wydziału (rada naukowa) mogła mianowicie wystąpić do CKK w sprawie bliższego określenia stopnia naukowego doktora habilitowanego. Mogła to uczynić tylko w dwóch przypadkach: (1) gdy nie było jednostki organizacyjnej zdolnej do przeprowadzenia przewodu habilitacyjnego, a także gdy żadna jednostka organizacyjna uprawniona do nadawania stopnia naukowego doktora habilitowanego w określonej dziedzinie nauki nie mogła przeprowadzić tego przewodu ze względu na brak wymaganej liczby osób posiadających tytuł naukowy lub stopień naukowy doktora habilitowanego w dyscyplinie odpowiadającej zakresowi rozprawy habilitacyjnej; (2) gdy przewód habilitacyjny dotyczył specjalności interdyscyplinarnej ${ }^{21}$.

\subsection{Wymagania w zakresie środowiska naukowego}

Ustawa z 1965 r. w jej pierwotnym brzmieniu nie wyjaśniała znaczenia pojęcia środowiska naukowego na odpowiednio wysokim poziomie. Od spełnienia tego wymagania warunkowała jednak uzyskanie przez szkoły wyższe, placówki naukowe PAN i instytuty naukowe oraz samodzielne placówki typu naukowo-dydaktycznego prawa do nadawania stopnia naukowego docenta w zakresie określonych dziedzin nauki lub dyscyplin naukowych. Do zdefiniowania poziomu środowiska naukowego zobowiązała Radę Ministrów ${ }^{22}$. Wydane przez nią rozporządzenie z dnia 8 lutego 1966 r. $^{23}$, w odróżnieniu od uchylonego nim rozporządzenia Rady Ministrów z 1959 r. ${ }^{24}$, ujmowało pojęcie to inaczej, szerzej. Przy ocenie poziomu środowiska naukowego instytucji ubiegającej się

${ }^{21}$ Zob. § 1 ust. 3 zarządzenia ministra nauki i szkolnictwa wyższego z dnia 18 VI $1986 \mathrm{r}$. w zw. z art. 7 ustawy z dnia 31 III 1965 r. w brzmieniu przyjętym w 1985 r. jej tekstem jednolitym (Obwieszczenie Ministra Nauki i Szkolnictwa Wyższego z dnia 11 IX 1985 r. w sprawie ogłoszenia jednolitego tekstu ustawy z dnia 31 III 1965. o stopniach naukowych i tytułach naukowych - Dz.U. Nr 42, poz. 202).

${ }^{22}$ Artykuł 25 ustawy z 1965 r. jednocześnie przyjął, że „[d]o czasu wydania przepisów wykonawczych, przewidzianych w ustawie, obowiązują przepisy dotychczasowe ze zmianami wynikającymi z niniejszej ustawy".

${ }^{23}$ Rozporządzenie Rady Ministrów z dnia 8 II 1966 r. w sprawie określenia warunków wymaganych do uzyskania prawa nadawania stopni naukowych (Dz.U. Nr 8, poz. 54).

${ }^{24}$ Rozporządzenie Rady Ministrów z dnia 12 VI 1959 r. w sprawie warunków uprawniających szkoły wyższe, placówki naukowe Polskiej Akademii Nauk i instytuty istniejące poza szkołami wyższymi do nadawania stopni naukowych (Dz.U. Nr 35, poz. 218). Szerzej zob. K. Wojtczak, Habilitacje w Polsce Ludowej, s. 40 i n. 
o prawo nadawania stopnia naukowego docenta nakazywało wziąć pod uwagę: (1) jej osiągnięcia w pracy naukowej w zakresie określonej dziedziny nauki lub dyscypliny naukowej, ze szczególnym uwzględnieniem wartości oryginalnych prac publikowanych lub wykonanych i zastosowanych opracowań (technologicznych, konstrukcyjnych, projektowych) istotnych dla postępu w nauce i technice; (2) dorobek naukowy zatrudnionych w instytucji pracowników naukowo-dydaktycznych w zakresie dyscypliny naukowej lub pracowników naukowo-badawczych specjalizujących się w dziedzinie nauki lub w zakresie dyscypliny naukowej, odpowiadającej uprawnieniu; (3) autorytet naukowy organu, mającego nadawać stopień naukowy docenta, uzasadniony jego składem osobowym; (4) zatrudnienie w pełnym wymiarze zajęć co najmniej dziesięciu pracowników ${ }^{25}$ z tytułami naukowymi lub ze stopniami naukowymi docenta, w tym co najmniej sześciu z tytułami profesora zwyczajnego lub profesora nadzwyczajnego ${ }^{26}$; (5) posiadanie odpowiednich środków, niezbędnych do dalszego rozwijania prowadzonych badań naukowych (aparatura, zaplecze warsztatowe, księgozbiór) ${ }^{27}$. Kryteria tej oceny uzupełniono rozporządzeniem nowelizującym z dnia 20 maja 1969 r. $^{28}$ Zobowiązano nim placówki naukowe PAN oraz instytuty naukowo-badawcze do posiadania rady naukowej o odpowiednim składzie osobowym ${ }^{29}$, zapewniającym prawidłową ocenę przedkładanych im prac.

${ }^{25}$ Przed 1965 r. próg ten był wyższy. Od wydziałów szkół wyższych (ale i placówek naukowych PAN) wymagano zatrudnienia w pełnym wymiarze zajęć co najmniej dwunastu samodzielnych pracowników nauki, w tej liczbie co najmniej sześciu z tytułem profesora zwyczajnego lub nadzwyczajnego, a spośród nich co najmniej jednego profesora reprezentującego dyscyplinę naukową lub gałąź nauki odpowiadającą tematowi rozprawy habilitacyjnej.

${ }^{26}$ Dla przyznania prawa do nadawania stopnia naukowego docenta odstapienie od tego wymagania było możliwe w wypadkach szczególnie uzasadnionych na podstawie pozytywnej opinii prezydium Rady Głównej Komisji Kwalifikacyjnej działającej przy PAN, wydanej $\mathrm{w}$ formie uchwały powziętej w trybie przewidzianym $\mathrm{w}$ regulaminach działania tych organów ( $\$ 3$ ust. 2 rozporządzenia z dnia 8 II 1966 r. w sprawie określenia warunków do uzyskania prawa nadawania stopni naukowych).

${ }^{27}$ Przyznanie uprawnień do nadawania stopnia naukowego docenta instytucjom spełniającym wymagania dotyczące poziomu środowiska naukowego leżało w gestii Przewodniczącego Komitetu Nauki i Techniki działającego w uzgodnieniu z ministrem szkolnictwa wyższego i z sekretarzem naukowym PAN (art. 2 ust. 2 ustawy).

${ }^{28}$ Rozporządzenie Rady Ministrów z dnia 20 V 1969 r. zmieniające rozporządzenie w sprawie określenia warunków wymaganych do uzyskania prawa nadawania stopni naukowych (Dz.U. Nr 16, poz. 117).

${ }^{29}$ Skład osobowy rady naukowej PAN określał jej statut. Zgodnie z nim radę naukową tworzyli: członkowie Akademii odpowiedniej specjalności oraz inni uczeni 
Oceny składu osobowego dokonywała Główna Komisja Kwalifikacyjna przy PAN.

Kolejne rozporządzenie z $1973 \mathrm{r} \cdot{ }^{30}$ tego stanu prawnego $\mathrm{w}$ istocie nie zmieniło. To, co nim wprowadzono jako rozwiązanie nowe, dotyczyło: odstąienia od przesłanki subiektywnej (autorytetu naukowego organu mającego nadawać stopień naukowy doktora habilitowanego); uzyskania pozytywnej opinii Centralnej Komisji Kwalifikacyjnej dla Kadr Naukowych (w miejsce pozytywnej opinii prezydium Rady Głównej Komisji Kwalifikacyjnej działającej przy PAN) w wypadkach szczególnie uzasadniających odstąpienie od zatrudnienia pracowników w pełnym wymiarze czasu pracy (co najmniej dziesięciu z tytułami naukowymi lub stopniami naukowymi doktora habilitowanego, w tym co najmniej sześciu z tytułami naukowymi).

Zmianę tego stanu rzeczy przyniosła dopiero znowelizowana w 1985 r. ustawa o stopniach naukowych i tytułach naukowych ${ }^{31}$. Zgodnie $\mathrm{z}$ nią uprawnienie do nadawania stopnia naukowego doktora habilitowanego mogła otrzymać jednostka organizacyjna, która: (1) zatrudniała co najmniej dwunastu pracowników z tytułem naukowym lub zajmujących stanowisko docenta ze stopniem naukowym doktora habilitowanego, reprezentujących dziedzinę nauki, w zakresie której jednostka ta mogła otrzymać uprawnienie, z tym że pracowników z tytułem naukowym nie mogło być mniej niż sześciu ${ }^{32}$, z zastrzeżeniem, że

reprezentujący dziedziny nauk, odpowiadające głównym kierunkom badań placów$\mathrm{ki}$, a także nauki pokrewne. Zatrudnienie w placówce nie stanowiło przeszkody do powołania w skład rady naukowej. Zob. § 26 ust. 2 Uchwały nr 385 Rady Ministrów z dnia 12 XII 1966 r. w sprawie nadania statutu organizacyjnego Polskiej Akademii Nauk (M.P. Nr 72, poz. 34). Skład rady naukowej instytutu naukowego tworzyli: przewodniczący (którym mógł być jedynie samodzielny pracownik naukowo-badawczy instytutu lub spoza instytutu albo osoba zajmująca stanowisko profesora lub docenta etatowego w szkole wyższej) oraz jako członkowie: samodzielni pracownicy naukowo-badawczy instytutu, a także spoza instytutu osoby posiadające tytuł naukowy profesora lub stopień naukowy docenta albo zajmujący stanowisko profesora lub docenta etatowego z zakresu dziedziny nauki lub dyscypliny naukowej stanowiącego główne kierunki prac naukowo-badawczych instytutu, a także wysoko wykwalifikowani praktycy z dziedziny objętej zakresem działania instytutu. Zob. art. 1 pkt 3 Ustawy z dnia 31 III 1965 r. o zmianie ustawy o instytutach naukowo-badawczych (Dz.U. Nr 14, poz. 100).

${ }^{30}$ Rozporządzenie Rady Ministrów z dnia 8 V 1973 r. w sprawie określenia warunków wymaganych do uzyskania prawa nadawania stopni naukowych (Dz.U. Nr 25, poz. 144).

${ }^{31}$ Ustawa z dnia 25 VII 1985 r. o zmianie ustawy o stopniach naukowych i tytułach naukowych (Dz.U. Nr 36, poz. 168).

32 Tylko szczególne przypadki mogły uzasadniać przyznanie prawa nadawania stopnia naukowego doktora habilitowanego jednostce organizacyjnej niespełniającej wymogu zatrudnienia (art. 2b ust. 2 ustawy z dnia 25 VII 1985 r.). 
dla nich zatrudniająca jednostka organizacyjna stanowiła podstawowe miejsce pracy; (2) uzyskała pozytywną ocenę poziomu działalności naukowej wydaną przez CKK na wniosek organu właściwego do podejmowania decyzji o nadaniu uprawnienia.

Przyznanie jednostkom spełniającym warunek poziomu środowiska naukowego prawa do nadawania stopnia naukowego docenta/doktora habilitowanego (w każdym przypadku na ich wniosek ${ }^{33}$ ) następowało (od 1965 do 1985 r.) w trybie i przez organy przewidziane do ustalania wykazów jednostek uprawnionych do nadawania tego stopnia naukowego ${ }^{34}$. Od roku 1985 uprawnienie to nadawali w porozumieniu z CKK: (1) minister nauki i szkolnictwa wyższego w porozumieniu z Radą Główną - w odniesieniu do jednostek organizacyjnych szkół wyższych, na wniosek ministra nadzorującego szkołę wyższą; (2) sekretarz naukowy PAN - w odniesieniu do jej placówek, w porozumieniu z ministrem nauki i szkolnictwa wyższego; (3) minister nauki i szkolnictwa wyższego - w odniesieniu do innych jednostek organizacyjnych, na wniosek ministra nadzorującego daną jednostkę.

Uprawnienie do nadawania stopnia naukowego mogło być cofnięte w całości albo w zakresie określonych dyscyplin naukowych, od $1985 \mathrm{r}$. mogło być także zawieszone. W przypadku pierwszym organ właściwy do ustalenia wykazu jednostek uprawnionych do nadawania stopnia naukowego (docenta/doktora habilitowanego) uprawnienie to cofał, jeżeli jednostka przestała odpowiadać warunkom stanowiącym podstawę do jego uzyskania $(1966,1973)$; w wyniku negatywnej oceny CKK oceniającej poziom naukowy rozpraw habilitacyjnych, a w razie potrzeby także poziom działalności naukowej stanowiącej podstawę

${ }^{33}$ Zob. dwa zarządzenia: pierwsze wydane przez Przewodniczącego Komitetu Naukowego i Techniki z dnia 11 V 1966 r. w sprawie trybu przygotowania wniosków o przyznanie uprawnień do nadawania stopni naukowych oraz wymaganej dokumentacji (M.P. Nr 23, poz. 121), drugie wydane przez Ministra Nauki, Szkolnictwa Wyższego i Techniki z dnia 9 IX 1974 r. w sprawie szczegółowego trybu przygotowania wniosków o przyznanie uprawnień do nadawania stopni naukowych (M.P. Nr 33, poz. 197), oraz Rozporządzenie Ministra Nauki i Szkolnictwa Wyższego z dnia 26 XI 1985 r. w sprawie zasad i trybu zgłaszania wniosków o przyznanie uprawnienia do nadawania stopni naukowych (Dz.U. Nr 56, poz. 287), uchylone z dniem 27 IX 1990 r. wraz z wejściem w życie ustawy z dnia 12 IX 1990 r. o tytule naukowym i stopniach naukowych.

${ }^{34}$ Chodziło tu o Przewodniczącego Komitetu Nauki i Techniki działającego w uzgodnieniu odpowiednio z ministrem szkolnictwa wyższego lub sekretarzem naukowym PAN, po zasięgnięciu opinii Rady Głównej Szkolnictwa Wyższego lub odpowiednio Głównej Komisji Kwalifikacyjnej działającej przy PAN; w latach 1973-1985 o ministra nauki, szkolnictwa wyższego i techniki działającego w porozumieniu z sekretarzem naukowym PAN i po zasięgnięciu opinii CKK. 
nadawania stopni naukowych $\mathrm{w}$ danej jednostce oraz podejmowanych uchwał (od 1985 r.). W przypadku drugim zawieszenie uprawnienia następowało z mocy prawa od dnia, w którym liczba zatrudnionych $\mathrm{w}$ jednostce organizacyjnej pracowników posiadających tytuł naukowy lub stopień naukowy doktora habilitowanego spadła poniżej minimum wymaganego, tj. poniżej dwunastu osób, w tym co najmniej sześciu $z$ tytułem naukowym ${ }^{35}$.

\subsection{Wykazy jako podstawa uprawnienia do nadawania stopnia naukowego}

Rozwiązania przyjęte ustawą o stopniach naukowych i tytułach naukowych nie miały w tym zakresie charakteru rewolucyjnego. Od dnia jej wejścia w życie zachowano obowiązek ustalania wykazów jednostek uprawnionych do nadawania stopni naukowych ${ }^{36}$, wraz z określeniem stopni naukowych, które mogły być przez nie nadawane. Jednostki (placówki) wykazem takim nieobjęte prawa w tym zakresie nie miały. Zmianom podlegały natomiast: organy ustawowo zobowiązane do ustalenia wykazów oraz jednostki nimi objęte, z uwzględnieniem zmian w zakresie dziedzin nauki i dyscyplin naukowych.

W brzmieniu pierwotnym ustawy z 1965 r. wykazy ustalał przewodniczący Komitetu Nauki i Techniki w uzgodnieniu z ministrem szkolnictwa wyższego i z sekretarzem naukowym PAN na wniosek: w szkołach wyższych i w samodzielnych placówkach naukowo-dydaktycznych - ministra sprawującego nad nimi nadzór, w placówkach naukowych PAN - sekretariatu naukowego PAN, w instytutach naukowo-badawczych - ministra, któremu instytut podlegał. W każdym wypadku zgłoszenie wniosku wymagało uprzednio zasięgnięcia opinii

${ }^{35} \mathrm{~W}$ razie cofnięcia uprawnienia ze względu na niższą od wymaganej liczbę osób posiadających tytuł naukowy lub stopień naukowy doktora habilitowanego w dyscyplinie odpowiadającej zakresowi rozprawy habilitacyjnej CKK działająca na wniosek rady (wydziału, naukowej) lub z własnej inicjatywy, w porozumieniu z ministrem nauki i szkolnictwa wyższego albo sekretarzem naukowym PAN w odniesieniu do jej placówek, mogła wyrazić zgodę na uzupełnienie składu rady (wydziału, naukowej) tej jednostki organizacyjnej o osoby niebędące członkami tej rady w sprawach danego przewodu habilitacyjnego.

${ }^{36}$ Do ich ogłaszania w Monitorze Polskim zobowiązywały rozporządzenia z dnia 8 II 1966 r. oraz z dnia 8 V 1973 r., a także znowelizowana w 1985 r. ustawa z dnia 31 III 1965 r. o stopniach naukowych i tytułach naukowych. 
Rady Głównej (w sytuacji pierwszej), Głównej Komisji Kwalifikacyjnej działającej przy PAN (w sytuacji drugiej i trzeciej). W 1973 r. zmieniono właściwość organów w tym zakresie. Ustalenie wykazów jednostek (placówek) uprawnionych do nadawania stopni naukowych wraz z ich określeniem należało do ministra nauki, szkolnictwa wyższego i techniki działającego $\mathrm{z}$ własnej inicjatywy lub na wniosek zainteresowanego ministra, w porozumieniu $z$ sekretariatem naukowym PAN i po zasięgnięciu opinii CKK. I tego stanu prawnego nie zmieniono do czasu wejścia w życie nowych rozwiązań w III Rzeczypospolitej ${ }^{37}$.

Pierwszym z wykazów ustalonych w 1966 r. ${ }^{38}$ objęto: jedną wyższa szkołę techniczną (Politechnikę Poznańską) i trzy wyższe szkoły rolnicze (w Olsztynie, w Poznaniu i we Wrocławiu) oraz jedną placówkę naukową PAN (Zakład Historii Nauki i Techniki). Z początkiem roku następnego ${ }^{39}$ wykaz ten rozszerzono o cztery akademie medyczne (Akademię Medyczną w Gdańsku, Akademię Medyczną w Krakowie, Akademię Medyczną w Warszawie i Akademię Medyczną we Wrocławiu) oraz o cztery instytuty naukowo-badawcze (Instytut Badawczy Leśnictwa, Instytut Badawczy Gruźlicy, Instytut Badawczy Uprawy, Nawożenia i Gleboznawstwa, Instytut Badawczy Weterynarii). Trzy miesiące później ${ }^{40}$ do ustalonych wcześniej wykazów dodano Uniwersytet Łódzki, Wyższą Szkołę Pedagogiczną w Krakowie oraz dwa instytuty naukowowo-badawcze (Instytut Badawczy Chemii Ogólnej oraz Instytut Hodowli i Aklimatyzacji Roślin). W lipcu tegoż roku ${ }^{41}$ - wykaz rozszerzono o dwie wyższe szkoły techniczne (Akademię Górniczo-Hutniczą w Krakowie i Politechnikę Warszawską), o Wyższą Szkołę Rolniczą w Krakowie oraz o Instytut Chemii Organicznej PAN. Kilka dni

${ }^{37}$ Zmieniały się natomiast nazwy urzędu ministra właściwego do spraw szkolnictwa wyższego. O zmianach w tym zakresie zob. K. Wojtczak, Prawne determinanty procesu kształcenia w szkołach wyższych w latach 1920-1990 (Część I), s. 67-72.

${ }^{38}$ Zarządzenie Przewodniczącego Komitetu Nauki i Techniki z dnia 19 XI 1966 r. w sprawie ustalenia wykazu jednostek uprawnionych do nadawania stopni naukowych (M.P. Nr 66, poz. 314).

${ }^{39}$ Zarządzenie Przewodniczącego Komitetu Nauki i Techniki z dnia 18 I 1967 r. w sprawie ustalenia wykazu jednostek uprawnionych do nadawania stopni naukowych (M.P. Nr 7, poz. 33).

${ }^{40}$ Zarządzenie Przewodniczącego Komitetu Nauki i Techniki z dnia 21 IV 1967 r. w sprawie ustalenia wykazu jednostek uprawnionych do nadawania stopni naukowych (M.P. Nr 26, poz. 119).

${ }^{41}$ Zarządzenie Przewodniczącego Komitetu Nauki i Techniki z dnia 31 VII 1967 r. w sprawie ustalenia wykazu jednostek uprawnionych do nadawania stopni naukowych (M.P. Nr 45, poz. 221). 
później, w sierpniu 1967 r., Przewodniczący Komisji Nauki i Techniki ustalił, w drodze zarządzenia, kolejny wykaz ${ }^{42}$ jednostek uprawnionych do nadawania stopni naukowych. Poza ich wskazaniem znaczenie tego aktu było głębsze. Na jego podstawie traciły moc obowiązującą wszystkie przepisy dotychczasowe $\mathrm{w}$ sprawie nadania jednostkom uprawnienia do nadawania stopni naukowych $(\S 4)$. Zarządzenie to w odniesieniu do stopnia docenta danej dziedziny nauk uzupełniono trzykrotnie oraz zmieniono, począwszy od 1969 r., już w odniesieniu do stopnia doktora habilitowanego, jedenaście razy. $W$ ten sposób uprawnieniem do nadawania stopnia naukowego docenta objęto: szkoły wyższe, placówki naukowe PAN oraz instytuty naukowo-badawcze. W grupie pierwszej uprawnienie w tym zakresie nabyło: siedem uniwersytetów (Uniwersytet Jagielloński w Krakowie, Uniwersytet Łódzki, Uniwersytet im. Marii Curie-Skłodowskiej w Lublinie, Uniwersytet im. Adama Mickiewicza w Poznaniu, Uniwersytet Mikołaja Kopernika w Toruniu, Uniwersytet Warszawski, Uniwersytet Wrocławski im. Bolesława Bieruta); trzy wyższe szkoły ekonomiczne (Szkoła Główna Planowania i Statystyki w Warszawie oraz Wyższa Szkoła Ekonomiczna w Krakowie i Wyższa Szkoła Ekonomiczna we Wrocławiu); jedna szkoła pedagogiczna (Wyższa Szkoła Pedagogiczna w Krakowie); siedem politechnik (Politechnika Gdańska, Politechnika Krakowska, Politechnika Łódzka, Politechnika Śląska im. Wincentego Pstrowskiego w Gliwicach, Politechnika Warszawska, Politechnika Wrocławska, Politechnika Poznańska), a także dwie wyższe szkoły techniczne (Akademia Górniczo-Hutnicza w Krakowie oraz Wojskowa Akademia Techniczna im. J. Dąbrowskiego w Warszawie); siedem wyższych szkół rolniczych (w Krakowie, w Lublinie, w Olsztynie, w Poznaniu, we Wrocławiu, w Szczecinie oraz Szkoła Główna Gospodarstwa Wiejskiego w Warszawie); dwie wyższe szkoły nauk społecznych i politycznych (Wyższa Szkoła Nauk Społecznych w Warszawie oraz Wojskowa Akademia Polityczna im. F. Dzierżyńskiego

${ }^{42}$ Zarządzenie z dnia 9 VIII 1967 r. w sprawie wykazu jednostek uprawnionych do nadawania stopni naukowych (M.P. Nr 50, poz. 248). Jednocześnie zarządzenie to w odniesieniu do dwóch jednostek organizacyjnych szkół wyższych (Wydziału Inżynierii Budowlanej Politechniki Warszawskiej oraz Wydziału Handlu Szkoły Głównej Planowania i Statystyki w Warszawie), na których wszczęto przewody habilitacyjne przed dniem jego wejścia w życie, przewidywało - w sytuacji pierwszej zakończenie przewodu habilitacyjnego z zakresu nauk matematycznych w Instytucie Matematyki Politechniki Warszawskiej, w sytuacji drugiej - możliwość zakończenia przewodu habilitacyjnego - na Wydziale Handlu. Wydziału Handlu nie objęto wykazem ustalonym zarządzeniem z dnia 9 VIII 1967 r. (§ 3). 
w Warszawie); dwie wyższe szkoły teologiczne (Akademia Teologii Katolickiej w Warszawie oraz Chrześcijańska Akademia Teologiczna w Warszawie); jedenaście akademii medycznych (Akademia Medyczna im. J. Marchlewskiego w Białymstoku, Akademia Medyczna w Gdańsku, Akademia Medyczna w Krakowie, Akademia Medyczna w Lublinie, Akademia Medyczna w Łodzi, Akademia Medyczna w Poznaniu, Akademia Medyczna w Warszawie, Akademia Medyczna we Wrocławiu, Pomorska Akademia Medyczna im. K. Świerczewskiego w Szczecinie, Śląska Akademia Medyczna im. L. Waryńskiego w Katowicach, Wojskowa Akademia Medyczna w Łodzi), uzupełnionych zarządzeniem z lipca 1968 r. ${ }^{43}$ o Studium Doskonalenia Lekarzy oraz jedną wyższą szkołę wychowania fizycznego (Akademia Wychowania Fizycznego im. gen. K. Świerczewskiego w Warszawie). W drugiej grupie wykazem tym objęto szesnaście placówek naukowych PAN, na mocy zarządzenia z dnia 31 lipca 1968 r. uzupełnionych o jedną placówkę (Instytut Automatyki) oraz w grupie trzeciej dziesięć instytutów naukowo-badawczych. W sumie stopień naukowy docenta w zakresie przewidzianym powyższymi zarządzeniami mogły nadawać: czterdzieści trzy szkoły wyższe na stu czterdziestu ośmiu wydziałach i w czterech instytutach; siedemnaście placówek naukowych PAN oraz, przy niezmienianej ich liczbie, dziesięć instytutów naukowo-badawczych.

Wprowadzone od czerwca 1969 r. zmiany zarządzenia z dnia 9 sierpnia 1967 r., poza zastąpieniem nazwy stopnia naukowego docenta stopniem naukowym doktora habilitowanego, bardzo ostrożnie rozszerzały wykazy o dalsze szkoły wyższe bądź ich jednostki organizacyjne oraz o placówki naukowe PAN i instytuty naukowo-badawcze. Gros zmian wynikało jednak z przekształceń jednostek organizacyjnych szkół wyższych (np. przez łączenie wydziałów lub tworzenie $z$ jednego dwóch wydziałów, z czym zwykle wiązało się nadanie im nowych nazw) bądź ze zmiany nazwy nieprzekształcanego wydziału, wcześniej uprawnionego do nadawania stopnia naukowego docenta. W efekcie zmian zapoczątkowanych zarządzeniem z dnia 2 czerwca 1969 r. ${ }^{44}$ liczbę jednostek odtąd uprawnionych do nadawania stopnia doktora habilitowanego

${ }^{43}$ Zarządzenie Przewodniczącego Komitetu Nauki i Techniki z dnia 31 VII 1968 r. w sprawie uzupełnienia wykazów jednostek uprawnionych do nadawania stopni naukowych (M.P. Nr 34, poz. 229).

${ }_{44}$ Zarządzenie Przewodniczącego Komitetu Nauki i Techniki z dnia 2 VI 1969 r. zmieniające zarządzenie w sprawie wykazu jednostek uprawnionych do nadawania stopni naukowych (M.P. Nr 23, poz. 183). 
rozszerzono o: jedną wyższą szkołę ekonomiczną (w Katowicach); jedną wyższą szkołę techniczną (Politechnikę Poznańską). Niewiele ponad trzy miesiące później zarządzeniem z września 1969 r. ${ }^{45} \mathrm{~W}$ grupie instytutów naukowo-badawczych uprawnieniem objęto Instytut Elektroniki. Tego samego roku w listopadzie ${ }^{46}$ prawo habilitowania rozszerzono o jedną wyższą szkołę techniczną (Politechnikę Szczecińską). $\mathrm{W}$ roku 1970 zarządzeniem z dnia 6 maja $^{47} \mathrm{~W}$ strukturę organizacyjną Wojskowej Akademii Medycznej w Łodzi włączono Instytut Kształcenia Podyplomowego w Warszawie z prawem nadawania stopnia doktora habilitowanego nauk medycznych, a zarządzeniem z dnia 22 września tegoż roku $^{48}$ do nadawania stopnia doktora habilitowanego uprawniono trzy kolejne instytuty naukowo-badawcze (Instytut Spraw Międzynarodowych, Instytut Medycyny Pracy w Przemyśle Włókienniczym i Chemicznym, Instytut Odlewnictwa). Rok 1971 tego stanu rzeczy wiele nie zmienił. Zarządzeniem z dnia 25 lutego ${ }^{49}$ Studium Doskonalenia Lekarzy włączono w strukturę Akademii Medycznej w Warszawie i uprawniono do nadawania stopnia doktora habilitowanego nauk medycznych; w grupie wyższych szkół ekonomicznych z wykazu skreślono jedną szkołę (Wyższą Szkołę Ekonomiczną w Sopocie).

W efekcie, $z$ uwzględnieniem zmian wprowadzonych zarządzeniem z dnia 9 sierpnia 1969 r., prawo do nadawania stopnia doktora habilitowanego miało: czterdzieści sześć szkół wyższych, łącznie na stu pięćdziesięciu ośmiu wydziałach i w pięciu instytutach, oraz jedna samodzielna placówka naukowo-dydaktyczna; siedemnaście placówek naukowych PAN, a także trzynaście instytutów naukowo-badawczych istniejących poza szkołami wyższymi.

${ }^{45}$ Zarządzenie Przewodniczącego Komitetu Nauki i Techniki z dnia 20 IX 1969 r. zmieniające zarządzenie w sprawie wykazu jednostek uprawnionych do nadawania stopni naukowych (M.P. Nr 43, poz. 346).

46 Zarządzenie Przewodniczącego Komitetu Nauki i Techniki z dnia 29 XI 1969 r. zmieniające zarządzenie w sprawie wykazu jednostek uprawnionych do nadawania stopni naukowych (M.P. Nr 51, poz. 401).

${ }^{47}$ Zarządzenie Przewodniczącego Komitetu Nauki i Techniki z dnia 6 V 1970 r. zmieniające zarządzenie w sprawie wykazu jednostek uprawnionych do nadawania stopni naukowych (M.P. Nr 15, poz. 130).

${ }^{48}$ Zarządzenie Przewodniczącego Komitetu Nauki i Techniki z dnia 22 IX 1970 r. zmieniające zarządzenie w sprawie wykazu jednostek uprawnionych do nadawania stopni naukowych (M.P. Nr 32, poz. 259).

49 Zarządzenie Przewodniczącego Komitetu Nauki i Techniki z dnia 25 II 1971 r. zmieniające zarządzenie w sprawie wykazu jednostek uprawnionych do nadawania stopni naukowych (M.P. Nr 15, poz. 109). 
Wraz z wejściem w życie kolejnego zarządzenia z dnia 26 listopada $1971 \mathrm{r}^{50}$ powyższe zarządzenia i przyjęte nimi wykazy utraciły moc prawną. Na tej technice legislacyjnej oparto także określenie mocy obowiązującej zarządzeń wydanych później, w latach: 1975, 1979, 1987 i $1988^{51}$. Każdorazowo kolejno wydane zarządzenie pozbawiało mocy obowiązującej zarządzenie wcześniejsze. Cztery z nich podlegały nowelizacjom: zarządzenie z 1971 r. osiem razy, zarządzenie z 1975 r. pięć razy, zarządzenie z 1979 r. dziesięć razy. Z dwóch ostatnich zarządzeń pierwsze, z 1987 r., nie zostało poddane zmianom, drugie zaś (z 1988 r.) zmieniono czterokrotnie, przy czym nie wszystkie zmiany odnosiły się do uprawnień do nadawania stopnia doktora habilitowanego. $Z$ kolei te z zarządzeń wraz z ich zmianami, które uprawnień do nadawania tego stopnia naukowego dotyczyły, wprawdzie ustalały wykazy jednostek (placówek) uprawnionych niejako od nowa, w istocie jednak nie niweczyły uprawnień w tym zakresie wcześniej nabytych przez większość $z$ nich. Po raz pierwszy wykazy uporządkowały instytucje uprawnione do nadawania stopnia doktora habilitowanego w czterech grupach: szkoły wyższe, samodzielne jednostki typu naukowo-dydaktycznego, placówki naukowe PAN oraz instytuty naukowo-badawcze.

Zarządzeniem z listopada 1971 r. w pierwszej grupie - szkoły wyższe, uprawnieniem do nadawania stopnia doktora habilitowanego objęto: osiem uniwersytetów (Uniwersytet Gdański ${ }^{52}$, Uniwersytet Jagielloński w Krakowie, Uniwersytet Marii Curie-Skłodowskiej w Lublinie, Uniwersytet Łódzki, Uniwersytet im. Adama Mickiewicza w Poznaniu,

${ }^{50}$ Zarządzenie Przewodniczącego Komitetu Nauki i Techniki z dnia 26 XI 1971 r. w sprawie wykazu jednostek organizacyjnych uprawnionych do nadawania stopni naukowych (M.P. Nr 58, poz. 378).

${ }^{51}$ Zarządzenie Ministra Nauki, Szkolnictwa Wyższego i Techniki z dnia 14 I 1975 r. w sprawie wykazu jednostek (placówek) uprawnionych do nadawania stopni naukowych (M.P. Nr 3, poz. 16); Zarządzenie Ministra Nauki, Szkolnictwa Wyższego i Techniki z dnia 13 IV 1979 r. w sprawie wykazu jednostek (placówek) uprawnionych do nadawania stopni naukowych (M.P. Nr 11, poz. 69); Zarządzenie Ministra Nauki i Szkolnictwa Wyższego z dnia 30 VII 1987 r. w sprawie wykazu jednostek organizacyjnych uprawnionych do nadawania stopni naukowych (M.P. Nr 23, poz. 191); Zarządzenie Ministra Edukacji Narodowej z dnia 28 VI 1988 r. w sprawie wykazu jednostek organizacyjnych uprawnionych do nadawania stopni naukowych (M.P. Nr 24, poz. 215).

${ }^{52}$ Uniwersytet Gdański powstał w 1970 r. w wyniku połączenia Wyższej Szkoły Pedagogicznej w Gdańsku z Wyższą Szkołą Ekonomiczną w Sopocie na mocy Rozporządzenia Rady Ministrów z dnia 20 III 1970 r. w sprawie utworzenia Uniwersytetu Gdańskiego (Dz.U. Nr 6, poz. 49). Na mocy tego rozporządzenia Uniwersytet Gdański mógł prowadzić działalność dydaktyczną i naukowo-badawczą w zakresie nauk humanistycznych, matematyczno-przyrodniczych oraz ekonomicznych. 
Uniwersytet Mikołaja Kopernika w Toruniu, Uniwersytet Warszawski, Uniwersytet Wrocławski im. Bolesława Bieruta we Wrocławiu); osiem politechnik (Politechnikę Gdańską, Politechnikę Śląską im. Wincentego Pstrowskiego w Gliwicach, Politechnikę Krakowska, Politechnikę Łódzką, Politechnikę Poznańską, Politechnikę Szczecińską, Politechnikę Warszawską i Politechnikę Wrocławską), a także Akademię Górniczo-Hutniczą im. Stanisława Staszica w Krakowie oraz Wojskową Akademię Techniczną im. Jarosława Dąbrowskiego w Warszawie; pięć wyższych szkół ekonomicznych (w Katowicach, w Krakowie, w Poznaniu, we Wrocławiu oraz Szkołę Główną Planowania i Statystyki w Warszawie); jedną wyższą szkołę pedagogiczną (w Krakowie); siedem wyższych szkół rolniczych (w Krakowie, w Lublinie, w Olsztynie, w Poznaniu, w Szczecinie, w Warszawie, we Wrocławiu); jedną wyższą szkołę nauk społecznych i politycznych (Wojskową Akademię Polityczną im. Feliksa Dzierżyńskiego w Warszawie); dwie wyższe szkoły teologiczne (Akademię Teologii Katolickiej w Warszawie oraz Chrześcijańską Akademię Teologiczną w Warszawie); jedenaście akademii medycznych (w Białymstoku, w Gdańsku, w Krakowie, w Lublinie, w Łodzi, w Poznaniu, w Warszawie, we Wrocławiu, a także Pomorską Akademię Medyczną im. Generała Karola Świerczewskiego w Szczecinie, Śląską Akademię Medyczną im. Ludwika Waryńskiego w Katowicach, Wojskową Akademię Medyczną w Łodzi); jedną wyższą szkołę wychowania fizycznego (Akademię Wychowania Fizycznego im. gen. broni Karola Świerczewskiego w Warszawie). Grupę drugą (samodzielne jednostki typu naukowo-dydaktycznego) reprezentowało Centrum Medyczne Kształcenia Podyplomowego ${ }^{53}$, z prawem do nadawania stopnia doktora habilitowanego nauk medycznych; w grupie trzeciej (placówki naukowe PAN) wykazem uprawniającym do nadawania stopnia doktora habilitowanego objęto siedemnaście instytutó ${ }^{54}$, a w grupie czwartej

${ }^{53}$ Centrum to powstało na mocy Rozporządzenia Rady Ministrów z dnia 9 X 1970 r. w sprawie utworzenia samodzielnej placówki naukowo-dydaktycznej pod nazwą Centrum Medyczne Kształcenia Podyplomowego (Dz.U. Nr 29, poz. 247).

${ }^{54}$ Uprawnieniem objęto: Instytut Automatyki (od 10 II 1972 r.), Instytut Cybernetyki Stosowanej (od 14 I 1975 r. Centrum Cybernetyki Stosowanej i Informatyki), Instytut Badań Literackich, Instytut Biochemii i Biofizyki, Instytut Biologii Doświadczalnej im. M. Nenckiego, Instytut Chemii Fizycznej, Instytut Chemii Organicznej, Instytut Filozofii i Socjologii, Instytut Fizyki, Instytut Geografii, Instytut Historii, Instytut Historii Kultury Materialnej, Instytut Immunologii i Terapii Doświadczalnej im. Ludwika Hirszfelda, Instytut Matematyczny, Instytut Nauk Prawnych, Instytut Podstawowych Problemów Techniki, Instytut Sztuki, Instytut Historii Nauki i Techniki. 
(instytuty naukowo-badawcze) jedenaście instytutów ${ }^{55}$. Nowele zmieniające zarządzenie $\mathrm{z}$ dnia 26 listopada 1971 r. wprawdzie zbytnio nie zmieniły ogólnej liczby przyjętych nimi szkół wyższych, jednak rozszerzały ogólną liczbę wydziałów uprawnionych do nadawania stopnia doktora habilitowanego ${ }^{56}$, a także poszerzyły grupę instytutów naukowo-badawczych o Instytut Higieny i Epidemiologii im. gen. Karola Kaczkowskiego ${ }^{57}$.

Zmiany dokonane $\mathrm{z}$ początkiem $1973 \mathrm{r} \cdot{ }^{58}$ ograniczono $\mathrm{w}$ istocie do wprowadzenia w nazwach dotychczasowych wyższych szkół rolniczych określeń akademia rolnicza, z wyjątkiem wyższej szkoły rolniczej w Olsztynie (dla której przyjęto nazwę Akademia Rolniczo-Techniczna w Olsztynie), ponadto rozszerzono listę instytutów naukowo-badawczych o Instytut Zootechniki. Niespełna rok później zarządzeniem z marca $1974 \mathrm{r} .{ }^{59}$ wykazem objęto dwie kolejne szkoły wyższe: Uniwersytet Śląski w Katowicach ${ }^{60}$ oraz Wyższą Szkołę Pedagogiczną im. Powstańców Śląskich w Opolu ${ }^{61}$. Ponadto w grupie wyższych szkół nauk społecznych i politycznych wykazem objęto Wyższą Szkołę Nauk

${ }^{55}$ Były to: Główny Instytut Górnictwa, Instytut Badawczy Leśnictwa, Instytut Chemii Przemysłowej, Instytut Elektrotechniki, Instytut Hodowli i Aklimatyzacji Roślin, Instytut Uprawy, Nawożenia i Gleboznawstwa, Instytut Weterynarii, Instytut Gruźlicy, Instytut Geologiczny, Instytut Badań Jądrowych oraz Państwowy Zakład Higieny.

${ }^{56}$ Zarządzenie Przewodniczącego Komitetu Nauki i Techniki z dnia 10 II 1972 r. zmieniające zarządzenie w sprawie wykazu jednostek organizacyjnych uprawnionych do nadawania stopni naukowych (M.P. Nr 14, poz. 97); Zarządzenie Ministra Nauki, Szkolnictwa Wyższego i Techniki z dnia 30 VIII 1972 r. zmieniające zarządzenie w sprawie wykazu jednostek organizacyjnych uprawnionych do nadawania stopni naukowych (M.P. Nr 44, poz. 235).

${ }^{57}$ Zarządzenie Ministra Nauki, Szkolnictwa Wyższego i Techniki z dnia 30 VIII 1972 r. zmieniające zarządzenie w sprawie wykazu jednostek organizacyjnych uprawnionych do nadawania stopni naukowych.

${ }^{58}$ Zarządzenie Ministra Nauki, Szkolnictwa Wyższego i Techniki z dnia 27 I 1972 r. zmieniające zarządzenie w sprawie wykazu jednostek organizacyjnych uprawnionych do nadawania stopni naukowych (M.P. Nr 7, poz. 46).

${ }^{59}$ Zarządzenie Ministra Nauki, Szkolnictwa Wyższego i Techniki z dnia 21 III 1974 r. zmieniające zarządzenie w sprawie wykazu jednostek organizacyjnych uprawnionych do nadawania stopni naukowych (M.P. Nr 12, poz. 90).

${ }^{60}$ Uniwersytet Śląski w Katowicach powstał z połączenia Wyższej Szkoły Pedagogicznej w Katowicach z Filią Uniwersytetu Jagiellońskiego w Katowicach - na mocy Rozporządzenia Rady Ministrów z dnia 8 VI 1968 r. w sprawie utworzenia Uniwersytetu Śląskiego w Katowicach (Dz.U. Nr 18, poz. 116).

${ }^{61}$ Zob. Rozporządzenie Rady Ministrów z dnia 20 IV 1971 r. w sprawie nadania Wyższej Szkole Pedagogicznej w Opolu imienia Powstańców Śląskich (Dz.U. Nr 10, poz. 105). 
Społecznych przy KC PZPR ${ }^{62}$ (z Wydziałem Nauk Społecznych ${ }^{63}$ ). Z wykazu placówek PAN skreślono natomiast Instytut Organizacji i Kierownictwa oraz dodano Centrum Cybernetyki Stosowanej i Informatyki.

Z uwzględnieniem zarządzeń zmieniających przed wejściem w życie kolejnego zarządzenia z 1975 r. do nadawania stopnia doktora habilitowanego w sumie uprawniono: czterdzieści dziewięć szkół wyższych (na stu sześćdziesięciu sześciu wydziałach i w dziesięciu instytutach), siedemnaście placówek naukowych PAN (ta niezmieniona liczba spowodowana była dodaniem jednej placówki i wykreśleniem z wykazu innej) oraz trzynaście instytutów naukowo-badawczych i jedną samodzielną jednostkę typu naukowo-dydaktycznego (w tym ostatnim przypadku liczba nie uległa więc zmianie).

Zarządzenia z lat 1975, 1979, 1988 i 1989 ustalające wykazy instytucji uprawnionych do nadawania stopnia doktora habilitowanego zachowały wcześniejszy układ ich ujęcia w czterech grupach: szkoły wyższe, samodzielne placówki typu naukowo-dydaktycznego, placówki naukowe PAN, instytuty naukowo-badawcze. Na przestrzeni tych lat liczba uprawnionych instytucji nieco się zmieniała, w szkołach wyższych z tendencją zwykle nieznacznie rosnąca, w placówkach naukowych PAN oraz instytutach naukowo-badawczych $z$ tendencją wyraźnie rosnącą.

Wraz z wejściem w życie zarządzenia z dnia 14 stycznia 1975 r. w grupie pierwszej, przy zachowaniu szkół wyższych objętych wykazem z listopada 1971 r., ich liczba utrzymała się na dotychczasowym poziomie czterdziestu dziewięciu (nieznacznie, bo do stu sześćdziesięciu ośmiu wzrosła łączna liczba wydziałów i instytutów); w 1979 r. było ich pięćdziesiąt ${ }^{64}$ ( $z$ łączną liczbą stu osiemdziesięciu czterech wydziałów i dziewięciu instytutów), w 1987 r. już pięćdziesiąt cztery ${ }^{65}$ (z dwustu jeden wydziałami i jednym instytutem), a w 1988 r. więcej o jedną szkołę wyższą

${ }^{62}$ Nazwę tej szkoły wyższej w 1984 r. zastąpiono nową nazwą - Akademia Nauk Społecznych w Warszawie na mocy Zarządzenia Ministra Nauki, Szkolnictwa Wyższego i Techniki z dnia 6 XI 1984 r. (M.P. Nr 26, poz. 175).

${ }^{63}$ Wydział Nauk Społecznych z wykazu skreślono Zarządzeniem Ministra Nauki, Szkolnictwa Wyższego i Techniki z dnia 22 VIII 1986 r. (M.P. Nr 27, poz. 190).

${ }^{64}$ Uprawnieniem do nadawania stopnia doktora habilitowanego objęto Katolicki Uniwersytet Lubelski (z Wydziałem Humanistycznym, od 1987 r. już z pięcioma wydziałami).

${ }^{65}$ W 1987 r. wykazem po raz pierwszy objęto: Uniwersytet Szczeciński (z Wydziałem Ekonomicznym), Politechnikę Częstochowską (z dwoma wydziałami), Akademię Medyczną w Bydgoszczy (z Wydziałem Lekarskim) oraz Akademię Wychowania Fizycznego im. Bronisława Czecha w Krakowie (z jednym wydziałem). 
(pięćdziesiąt pięć6 ${ }^{66}$ ) ze zmniejszoną łączną liczbą wydziałów do stu dziewięćdziesięciu sześciu i zwiększoną liczbą instytutów do dziewięciu. W grupie drugiej w latach 1975 i 1979 nie wprowadzono zmian, prawo do nadawania stopnia doktora habilitowanego zachowano dla jednej samodzielnej placówki naukowo-dydaktycznej (Centrum Medycznego Kształcenia Podyplomowego w Warszawie), w 1987 r. grupę tę rozszerzono o kolejną placówkę (Specjalistyczny Zespół Opieki Zdrowotnej - Pomnik Centrum Zdrowia Dziecka), i tego stanu rzeczy w 1988 r. nie zmieniono. Liczba placówek naukowych PAN w 1975 r. utrzymała się na poziomie z roku 1971 (siedemnastu placówek), a w latach następnych zmian wzrosła do dwudziestu (w $1979 \mathrm{r} .^{67}$ ) oraz trzydziestu jeden (w $1987 \mathrm{r}^{68}{ }^{68}$; w zarządzeniu ministra edukacji narodowej z dnia 28 czerwca $1988 \mathrm{r}$. ten stan liczbowy nie uległ zmianie. Z kolei liczba instytutów naukowo-badawczych od 1971 do 1975 r. ${ }^{69}$ wzrosła z trzynastu do piętnastu. W roku 1979 było ich już dwadzieścia trzy ${ }^{70}$, w 1987 i 1988 r. trzydzieści ${ }^{71}$. Wyraźnie dostrzec można w tych latach zmianę proporcji

\footnotetext{
${ }^{66}$ W roku 1988 wykazem nadto objęto Wojskową Akademię Polityczną im. Feliksa Dzierżyńskiego w Warszawie.

${ }^{67}$ Zarządzeniem ministra nauki, szkolnictwa wyższego i techniki z dnia 13 IV 1979 r.
} dodano trzy nowe placówki PAN: Instytut Ekologii, Instytut Niskich Temperatur i Badań Strukturalnych, Centrum Medycyny Doświadczalnej i Klinicznej. Nazwę dotychczasową Instytutu Nauk Prawnych zastąpiono nazwą Instytut Państwa i Prawa, a nazwę dotychczasową Instytut Organizacji i Kierownictwa. Centrum Cybernetyki Stosowanej i Informatyki zastąpiono nazwą Instytut Podstaw Informatyki.

${ }^{68}$ Nowo powstałe placówki naukowe PAN to: Instytut Badań Systemowych, Instytut Biocybernetyki i Inżynierii Biomedycznej, Instytut Centrum Medycyny Doświadczalnej i Klinicznej, Instytut Fizyki Molekularnej, Instytut Genetyki i Hodowli Zwierząt, Instytut Geofizyki, Instytut Języka Polskiego, Instytut Maszyn Przepływowych, Instytut Nauk Geologicznych, Instytut Parazytologii im. Witolda Stefańskiego oraz Instytut Podstaw Metalurgii im. Aleksandra Krupkowskiego.

${ }^{69}$ Zarządzeniem ministra nauki, szkolnictwa wyższego i techniki z dnia 14 I 1975 r. rozszerzono wykaz instytutów naukowo-badawczych o: Instytut Ochrony Roślin oraz o Instytut Reumatologiczny.

${ }^{70}$ Zarządzeniem ministra nauki, szkolnictwa wyższego i techniki z dnia 13 IV 1979 r. wykazem instytutów naukowo-badawczych ponadto objęto: Instytut Fizyki Jądrowej, Wojskowy Instytut Medycyny Lotniczej, Instytut Mechaniki Precyzyjnej, Instytut Ekonomiki Rolnej, Instytut Sadownictwa i Kwiaciarstwa, Instytut Hematologii, Instytut Matki i Dziecka, Instytut Onkologii im. Marii Skłodowskiej-Curie.

${ }^{71}$ Zarządzeniem ministra nauki i szkolnictwa wyższego z dnia 30 VII 1987 r. wcześniejszy wykaz instytutów naukowo-badawczych rozszerzono zarówno o instytuty nowe, jak i o niektóre $\mathrm{z}$ tych utworzonych zarządzeniami zmieniającymi zarządzenie $\mathrm{z}$ dnia 13 IV 1979 r. Dla niektórych z nich dotychczasowe nazwy zastąpiono nazwami nowymi. 
instytucji uprawnionych do nadawania stopnia doktora habilitowanego z przewagą liczebną na rzecz placówek naukowych PAN i instytutów naukowo-badawczych. W 1971 r. na czterdzieści dziewięć szkół wyższych przypadało trzydzieści placówek naukowych PAN oraz instytutów naukowo-badawczych uprawnionych do nadawania stopnia doktora habilitowanego; w roku 1975 liczba szkół wyższych nie uległa zmianie, zwiększono natomiast do trzydziestu dwóch liczbę placówek PAN i instytutów naukowo-badawczych. W 1979 r. różnica w proporcji między nimi malała - na pięćdziesiąt szkół wyższych przypadały czterdzieści trzy placówki PAN i instytuty naukowo-badawcze; w 1987 r. stosunek ten zmienił się już na korzyść uprawnionych placówek PAN i instytutów naukowo-badawczych w łącznej liczbie sześćdziesięciu jeden wobec liczby pięćdziesięciu czterech szkół wyższych. Wprawdzie zarządzenie z dnia 28 czerwca 1988 r. różnicy tej już wiele nie zmieniło, z pięćdziesięciu czterech do pięćdziesięciu pięciu wzrosła liczba szkół wyższych, jednak przepisy zmieniające to zarządzenie powiększały ją na korzyść

\footnotetext{
Nowo utworzonymi instytutami były: Instytut Meteorologii i Gospodarki Wodnej, Polski Instytut Spraw Międzynarodowych, Instytut Medycyny Pracy im. prof. dr. med. Jerzego Nofera, Instytut Psychiatrii i Neurologii. Z kolei instytutami naukowo-badawczymi utworzonymi po 1979 r. i objętymi wykazem z 1987 r. były: Instytut Psychoneurologiczny (Zarządzenie Ministra Nauki i Szkolnictwa Wyższego z dnia 18 VI 1982 r. - M.P. Nr 16, poz. 131; w 1987 r. już nieobjęty wykazem), Instytut Budownictwa, Mechanizacji i Elektryfikacji Rolnictwa, Instytut Gospodarki Narodowej (Zarządzenie Ministra Nauki, Szkolnictwa Wyższego i Techniki z dnia 9 XI 1982 r. - M.P. Nr 27, poz. 242), Instytut Technologii Elektronowej (Zarządzenie Ministra Nauki, Szkolnictwa Wyższego i Techniki z dnia 5 X 1983 r. - M.P. Nr 33, poz. 182), Instytut Melioracji i Użytków Zielonych (Zarządzenie Ministra Nauki, Szkolnictwa Wyższego i Techniki z dnia 11 II 1984 r. - M.P. Nr 4, poz. 36), Instytut Problemów Jądrowych (Zarządzenie Ministra Nauki i Szkolnictwa Wyższego z dnia 22 VIII 1986 r. - M.P. Nr 27, poz. 190), Wojskowy Instytut Historyczny im. Wandy Wasilewskiej (Zarządzenie Ministra Nauki i Szkolnictwa Wyższego z dnia 17 XII 1986 r. - M.P. Nr 1, poz. 4). Skreślono Instytut Badań Jądrowych (zarządzenie ministra nauki, szkolnictwa wyższego i techniki z dnia 5 X 1983 r.); wykazem nie objęto Instytutu Chemii Przemysłowej. Instytut Planowania (wprowadzony Zarządzeniem Ministra Nauki, Szkolnictwa Wyższego i Techniki z dnia 17 V 1980 r. - M.P. Nr 14, poz. 66) skreślono z wykazu ustalonego Zarządzeniem Ministra Nauki, Szkolnictwa Wyższego i Techniki z dnia 18 VI 1982 r. - M.P. Nr 16, poz. 131). Zmiany nazw nastąpiły w odniesieniu do: Instytutu Ekonomiki Rolnej, który otrzymał nazwę Instytut Ekonomii Rolnictwa i Gospodarki Żywnościowej (zarządzenie ministra nauki, szkolnictwa wyższego i techniki z dnia 5 X 1983 r.) oraz Instytutu Onkologii im. Marii Skłodowskiej-Curie przemianowanego na Centrum Onkologii - Instytut im. Marii Skłodowskiej-Curie (Zarządzenie Ministra Nauki, Szkolnictwa Wyższego i Techniki z dnia 5 XI 1984 r. - M.P. Nr 26, poz. 175); ponadto wykazem z 1987 r. nazwę Instytutu Gruźlicy zastąpiono nazwą Instytut Gruźlicy i Chorób Płuc (zarządzenie ministra nauki i szkolnictwa wyższego z dnia 30 VII 1987 r.).
} 
placówek PAN i instytutów naukowo-badawczych. W zarządzeniu z dnia 5 kwietnia 1989 r. ${ }^{72}$ prawo habilitowania nabyła kolejna placówka PAN (Zakład Nauk Zarządzania) oraz kolejny instytut naukowo-badawczy (Instytut Kardiologii), cztery miesiące później tego samego roku kolejnym zarządzeniem ${ }^{73}$ utworzono nową placówkę naukową PAN (Instytut Słowianoznawstwa), a po blisko roku zarządzeniem z $1990 \mathrm{r}^{74}$ także Instytut Farmakologii. Zarządzeniem $z$ tej samej daty do liczby pięćdziesięciu sześciu wzrosła liczba szkół wyższych ${ }^{75}$. Z kolei zarządzeniem z września 1990 r. ${ }^{76}$ liczbę instytutów naukowych (od marca 1990 r. nazywanych jednostkami badawczo-rozwojowymi ${ }^{77}$ ) powiększono o kolejną jednostkę (Instytut Metalurgii Żelaza im. Stanisława Staszica).

W sumie do czasu wejścia w życie nowych przepisów wykonawczych na mocy Ustawy z dnia 12 września 1990 r. o tytule naukowym i stopniach naukowych ${ }^{78}$ ustalających wykazy jednostek uprawnionych do nadawania stopnia doktora habilitowanego prawo w tym zakresie miało: pięćdziesiąt sześć szkół wyższych oraz sześćdziesiąt sześć jednostek naukowych, z czego trzydzieści cztery placówki naukowe PAN i trzydzieści dwa instytuty naukowo-badawcze. Mierząc natomiast ten stosunek liczbą uprawnień do nadawania stopnia naukowego docenta oraz stopnia doktora habilitowanego, proporcje te wyglądaja zgoła odmiennie. W najwięcej, bo w dwieście dziewięć uprawnień do nadawania stopnia naukowego docenta wyposażono szkoły wyższe ogółem; osiemnaście uprawnień nabyły placówki naukowe PAN oraz dwadzieścia jeden - instytuty naukowo-badawcze. Liczba uprawnień

72 Zarządzenie Ministra Edukacji Narodowej z dnia 8 IV 1989 r. zmieniające zarządzenie w sprawie wykazu jednostek organizacyjnych uprawnionych do nadawania stopni naukowych (M.P. Nr 12, poz. 97).

${ }^{73}$ Zarządzenie Ministra Edukacji Narodowej z dnia 21 VIII 1989 r. zmieniające zarządzenie w sprawie wykazu jednostek organizacyjnych uprawnionych do nadawania stopni naukowych (M.P. Nr 32, poz. 246).

${ }_{74}$ Zarządzenie Ministra Edukacji Narodowej z dnia 1 III 1990 r. zmieniające zarządzenie w sprawie wykazu jednostek organizacyjnych uprawnionych do nadawania stopni naukowych (M.P. Nr 11, poz. 85).

${ }^{75}$ Prawo do nadawania stopnia doktora habilitowanego uzyskała Akademia Wychowania Fizycznego we Wrocławiu.

${ }^{76}$ Zarządzenie Ministra Edukacji Narodowej z dnia 24 IX 1990 r. zmieniające zarządzenie w sprawie wykazu jednostek organizacyjnych uprawnionych do nadawania stopni naukowych (M.P. Nr 35, poz. 284).

77 Zob. § 1 pkt 3 część D Zarządzenia Ministra Edukacji Narodowej z dnia 1 III 1990 r. zmieniające zarządzenie w sprawie wykazu jednostek organizacyjnych uprawnionych do nadawania stopni naukowych (M.P. Nr 11, poz. 85).

${ }^{78}$ Dz.U. Nr 65, poz. 386. 
do nadawania stopnia doktora habilitowanego, począwszy od 1968 r., rosła i w wykazach ustalanych w kolejnych latach do 1990 r. wynosiła odpowiednio: trzydzieści jeden uprawnień dla szkół wyższych, jedno uprawnienie dla instytutu naukowo-badawczego oraz jedno uprawnienie (od 25 lutego 1971 r.) dla placówki typu naukowo-dydaktycznego. Zgodnie z nowym wykazem z 1971 r. szkoły wyższe miały dwieście trzy uprawnienia do nadawania stopnia doktora habilitowanego, jedno (i tu bez zmian) placówka typu naukowo-dydaktycznego, dziewiętnaście uprawnień PAN, a szesnaście uprawnień - instytuty naukowo-badawcze. W wykazie z 1975 r. szkoły wyższe dysponowały już dwustu dwudziestoma pięcioma uprawnieniami, nie zmieniła się liczba uprawnień jedynej placówki typu naukowo-dydaktycznego, wzrosła z szesnastu do dziewiętnastu liczba uprawnień w placówkach naukowych PAN oraz z szesnastu do dwudziestu dwóch - w instytutach naukowo-badawczych. W wykazie z 1979 r. dla szkół wyższych rozszerzono liczbę uprawnień do dwustu czterdziestu jeden, nie zmieniła się liczba uprawnień jedynej placówki typu naukowo-dydaktycznego, placówki naukowe PAN miały dwadzieścia cztery uprawnienia, a instytuty naukowo-badawcze trzydzieści jeden uprawnień. W dwóch następnych latach wielkości te zmieniły się nieznacznie i w 1987 r. szkoły wyższe dysponowały ogółem trzystu czterdziestoma pięcioma uprawnieniami, a w 1988 r. miały ich trzysta pięćdziesiąt jeden. Z jednej do dwóch zwiększyła się w 1987 r. liczba jednostek typu naukowo-dydaktycznego oraz z dwóch do trzech liczba ich uprawnień, przy niezmienionej ich liczbie w $1988 \mathrm{r}$. Z kolei placówki naukowe PAN w roku 1987 miały trzydzieści pięć uprawnień, a w 1988 r. czterdzieści trzy. Natomiast instytuty naukowo-badawcze w 1987 r. miały trzydzieści uprawnień, a w 1988 r. trzydzieści siedem. Oczywiście, przyrost ten nie jest równoznaczny z ogólną liczbą dziedzin nauk i dyscyplin naukowych przewidzianych ówczesnymi przepisami prawnymi dla nadawania stopnia doktora habilitowanego. Jest liczba uprawnień nadanych wydziałom, placówkom, instytutom, z których niektóre dysponowały więcej niż jednym uprawnieniem.

\section{Warunki i przebieg przewodów habilitacyjnych}

Podobnie jak w rozwiązaniach $\mathrm{z}$ lat wcześniejszych ustawa $\mathrm{z}$ dnia 31 marca 1965 r. w wąskim zakresie normowała zagadnienie przewodów habilitacyjnych. Określała zakres wymagań stawianych jednostkom 
organizacyjnym uprawnionym do nadawania stopnia naukowego docenta/doktora habilitowanego, wskazywała, kto mógł być dopuszczony do przewodu habilitacyjnego, warunki, jakim powinna odpowiadać rozprawa habilitacyjna, a także tryb postępowania w zakresie podejmowania uchwał kończących przewód habilitacyjny. Zarazem upoważniała Radę Ministrów do określenia, w drodze rozporządzenia, warunków i trybu przeprowadzania przewodów habilitacyjnych (delegacja obligatoryjna) oraz ministra szkolnictwa wyższego i sekretarza naukowego PAN do określenia wspólnie szczegółowych warunków, jakim powinny odpowiadać rozprawy habilitacyjne oraz zakres kolokwium habilitacyjnego (delegacja fakultatywna). Wydane przez Radę Ministrów rozporządzenie z dnia 8 lutego 1966 r. ${ }^{79}$, do czasu jego uchylenia w połowie 1985 r., znowelizowano dwukrotnie. Istotne zmiany w tym zakresie przyniosła ustawa $\mathrm{z}$ dnia 25 lipca $1985 \mathrm{r} .{ }^{80}$ nowelizująca ustawę o stopniach naukowych i tytułach naukowych oraz wydane na jej podstawie zarządzenie ministra nauki i szkolnictwa wyższego z dnia 11 marca $1986 \mathrm{r}^{81}$, także dwa razy zmienione.

Przewody habilitacyjne mogły przeprowadzać tylko jednostki (placówki) uprawnione do nadawania stopni naukowych w określonej dziedzinie nauki lub dyscyplinie naukowej. Zgodnie z ustawą z 1965 r. w jej pierwotnym brzmieniu oraz rozporządzeniem Rady Ministrów z dnia 8 lutego 1966 r. uprawnieniem mogły być objęte tylko te dziedziny nauki, dla których wśród zatrudnionych pracowników (naukowo-dydaktycznych lub naukowo-badawczych albo członków rady naukowej) znajdował się co najmniej jeden specjalista $z$ tytułem profesora lub ze stopniem naukowym docenta - reprezentujący dyscyplinę naukową odpowiadającą tematowi rozprawy habilitacyjnej. Przy czym, jeżeli ze względu na temat rozprawy habilitacyjnej: (1) żadna z instytucji uprawnionych nie odpowiadała w pełni powyższemu warunkowi lub (2) istniały trudności w ustaleniu instytucji właściwej do przeprowadzenia przewodu habilitacyjnego w określonej dziedzinie nauki lub dyscyplinie naukowej - minister sprawujący nadzór nad szkołą wyższą lub

${ }^{79}$ Rozporządzenie Rady Ministrów z dnia 8 II 1966 r. w sprawie warunków i trybu przeprowadzania przewodów doktorskich i habilitacyjnych (Dz.U. Nr 8, poz. 53 ze zm.).

${ }^{80}$ Dz.U. Nr 36, poz. 168.

${ }^{81}$ Zarządzenie Ministra Nauki i Szkolnictwa Wyższego z dnia 11 III 1986 r. w sprawie szczegółowych warunków i trybu przeprowadzania przewodów doktorskich i habilitacyjnych oraz zakresu egzaminów doktorskich i kolokwiów habilitacyjnych (M.P. Nr 11, poz. 74). 
sekretarz naukowy PAN decydował, która z uprawnionych instytucji jest właściwa do przeprowadzenia przewodu habilitacyjnego. Zarazem mógł jej radę (wydziału, naukową) zobowiązać, by ta zaprosiła do udziału w przewodzie wybitnych specjalistów z dziedziny nauki lub dyscypliny naukowej właściwej ze względu na temat rozprawy habilitacyjnej ( 18 w zw. z § 1 ust. 3 rozporządzenia).

Rok 1985 r. uwarunkowania te dość istotnie zmienił. Zgodnie z ustawą zmieniającą ustawę z $1965 \mathrm{r}$. uprawnienie do nadawania stopnia doktora habilitowanego mogło obejmować tylko te dyscypliny nauki, które w danej jednostce organizacyjnej były reprezentowane przez co najmniej pięciu pracowników z tytułem naukowym lub stopniem naukowym doktora habilitowanego (art. 2 a ust. 2 i ust. 3 ustawy). W razie zmniejszenia się tej liczby pracowników (poniżej wymaganego minimum) uprawnienie do nadawania stopnia naukowego doktora habilitowanego od tego dnia ulegało zawieszeniu z mocy prawa. Przy czym CKK, działając na wniosek rady wydziału (rady naukowej) lub $\mathrm{z}$ własnej inicjatywy w porozumieniu $\mathrm{z}$ ministrem nauki i szkolnictwa wyższego albo sekretarzem naukowym PAN w odniesieniu do jej placówek, mogła podjąć w tym przypadku stosowne działania. Mogła wyrazić zgodę na uzupełnienie składu rady (wydziału, naukowej) tej jednostki organizacyjnej o osoby niebędące członkami tej rady. Osoby uzupełniające skład rady wydziału (rady naukowej) miały uprawnienia członka tejże rady w sprawach danego przewodu habilitacyjnego. CKK mogła to uczynić tylko wtedy, gdy żadna jednostka uprawniona do nadawania stopnia doktora habilitowanego w określonej dziedzinie nauki nie mogła przeprowadzić takiego przewodu ze względu na brakującą liczbę co najmniej pięciu osób posiadających tytuł naukowy lub stopień naukowy doktora habilitowanego w dyscyplinie odpowiadającej zakresowi rozprawy habilitacyjnej (art. 2e w zw. z art. 2a ust. 3 ustawy).

$\mathrm{Z}$ kolei wydane na podstawie tejże ustawy zarządzenie $\mathrm{z}$ dnia 11 marca 1986 r. zachowało wcześniej stawiane przed radami (wydziałów, naukowymi) wymaganie, by wśród członków rady (w porównaniu z rozwiązaniami z 1966 r. tu bez wyboru opcji) zatrudnionych w jednostce organizacyjnej znajdował się co najmniej jeden pracownik z tytułem naukowym lub stopniem naukowym doktora habilitowanego zajmujący stanowisko docenta, reprezentujący specjalność odpowiadającą tematowi rozprawy habilitacyjnej ( $\$ 16$ ust. 2 zarządzenia).

Wzorem rozwiązań wcześniejszych do przewodu habilitacyjnego mogła być dopuszczona osoba, która posiadając stopień naukowy 
doktora, uzyskała znaczny dorobek naukowy i przedłożyła rozprawę habilitacyjną (art. 9 ustawy). W odróżnieniu od nich ustawa z 1965 r. nie przewidywała (i trafnie) odstąpienia od obowiązku posiadania stopnia naukowego doktora - i warunek ten zachowała do 1990 r. Zmianom do tego roku nie podlegały także pozostałe przesłanki stanowiące podstawę dopuszczenia kandydata do przewodu habilitacyjnego, poza jedną przesłanką dodaną. Ustawa nowelizująca z 1985 r. od kandydata nadto wymagała wykazania nienagannej postawy obywatelskiej. Bez większej zmiany pozostały również te dyspozycje ustawodawcy, które dla wszczęcia przewodu habilitacyjnego wymagały złożenia przez kandydata stosownego podania ${ }^{82}$.

Innej ocenie podlegają warunki i tryb przeprowadzania przewodu habilitacyjnego. W okresie objętym analizą uwarunkowania prawne $\mathrm{w}$ tym zakresie podlegały zmianom. Wbrew przewidywaniom za ich wprowadzeniem nie przemawiała cezura czasowa wyznaczająca przejście od stopnia naukowego docenta do stopnia doktora habilitowanego. Przeciwnie, istotne zmiany wyznaczały inne uwarunkowania, zmierzające $w$ dwóch przeciwstawnych kierunkach: zliberalizowania prawa do 1985 r. i jego zaostrzenia po tym roku. Rozwiązania z lat 1965-1985 znacznie złagodziły zarówno wymagania przewidziane prawem szkolnictwa wyższego z 1958 r. stawiane przed instytucjami ubiegającymi się o uprawnienie do nadawania stopnia naukowego docenta/doktora habilitowanego (m.in. wyraźnie obniżono tzw. próg zatrudnienia), jak i dotyczące przeprowadzania przewodów habilitacyjnych (m.in. po raz pierwszy od roku 1920 przebiegiem przewodu habilitacyjnego nie objęto wykładu habilitacyjnego). W latach 1985-1990 wymagania te zaostrzono. Wyrazem zaostrzenia regulacji było nie tylko przywrócenie wielu rozwiązań przyjętych ustawą z 1958 r., ale też wprowadzenie

${ }^{82}$ Do podania składanego dziekanowi wydziału (kierownikowi placówki, instytutu) kandydat był obowiązany dołączyć: w oryginale lub w uwierzytelnionym odpisie dokument stwierdzający uzyskanie stopnia naukowego doktora, dokładny życiorys ze szczególnym przedstawieniem przebiegu swojej pracy zawodowej i naukowej, wykaz opublikowanych prac naukowych oraz rozprawę habilitacyjną w pięciu egzemplarzach ( 21 rozporządzenia z dnia 8 II 1966 r.), od 1986 r. uzupełniony o przedstawienie informacji o przebiegu i wynikach przeprowadzonego postępowania habilitacyjnego w sytuacji, gdy wnoszący podanie wcześniej przedstawił rozprawę habilitacyjną w innej jednostce organizacyjnej jako podstawę przewodu habilitacyjnego ( $\$ 18$ ust. 3 Zarządzenia Ministra Nauki i Szkolnictwa Wyższego z dnia 11 III 1986 r. w sprawie szczegółowych warunków i trybu przeprowadzania przewodów doktorskich i habilitacyjnych oraz zakresu egzaminów doktorskich i kolokwiów habilitacyjnych - M.P. Nr 11, poz. 74). 
rozwiązań nowych, podwyższających wymagania. Te sprowadzały się m.in. do zakresu warunków niezbędnych do nabycia uprawnienia do nadawania stopnia naukowego doktora habilitowanego. Także w odniesieniu do trybu i warunków przebiegu przewodu habilitacyjnego przepisy zaostrzono. Można zatem mówić o warunkach i trybie przeprowadzania przewodów habilitacyjnych ukształtowanych prawem obowiązującym przed rokiem 1985 oraz po tej dacie.

\subsection{Przebieg przewodu habilitacyjnego w latach 1966-1985}

Na mocy ustawy z 1965 r. i rozporządzenia z dnia 8 lutego 1966 r. $^{83}$ przewód habilitacyjny obejmował:

1. wszczęcie przewodu habilitacyjnego, z czym wiązał się spoczywający na radzie (wydziału, naukowej) obowiązek powołania spośród swych członków komisji w składzie co najmniej trzech osób (złożonej z pracowników naukowo-dydaktycznych lub naukowo-badawczych z tytułem naukowym profesora lub ze stopniem naukowym docenta, z których większość miała posiadać tytuł profesora). Skład osobowy komisji mógł być ponadto uzupełniony przez jednego lub dwóch wybitnych specjalistów z dziedziny właściwej dla rozprawy habilitacyjnej spoza instytucji przeprowadzającej przewód habilitacyjny. Do obowiązku komisji należało, po zaznajomieniu się z dorobkiem naukowym kandydata oraz przedmiotem i zakresem rozprawy habilitacyjnej, przedstawienie radzie wniosku ${ }^{84} \mathrm{~W}$ sprawie wszczęcia przewodu;

2. ocenę dorobku naukowego kandydata ze szczególnym uwzględnieniem przedłożonej rozprawy habilitacyjnej. Zbliżonej treści rozwiązanie przyjęła także ustawa z 1958 r. o szkołach wyższych ${ }^{85}$. W przeciwieństwie do niej ustawa z 1965 r., mimo że nie wyjaśniała znaczenia pojęcia dorobku naukowego kandydata, wyraźniej podkreślała znaczenie obu komponentów oceny (dorobku naukowego i rozprawy habilitacyjnej) w recenzjach habilitacyjnych. Rozprawa habilitacyjna miała stanowić poważny (w 1958 r. twórczy) wkład kandydata w rozwój

${ }^{83}$ Rozporządzenie Rady Ministrów z dnia 8 II 1966 r. w sprawie warunków i trybu przeprowadzania przewodów doktorskich i habilitacyjnych.

${ }^{84}$ Wniosek komisji wymagał formy uchwały podjętej przy obecności co najmniej połowy ogólnej liczby jej członków, w głosowaniu tajnym większością dwóch trzecich głosów; od 1969 r. większością głosów.

${ }^{85} \mathrm{Na}$ ten temat zob. K. Wojtczak, Habilitacje w Polsce Ludowej, s. 52 i n. 
określonej dziedziny nauki lub dyscypliny naukowej. Przy dochowaniu tego warunku mogła jednak także polegać (i jest to rozwiązanie nowe) na: (1) syntetycznym i systematycznym ujęciu innych prac kandydata, (2) opracowaniu problematyki całości lub poważnej części danej dyscypliny naukowej, polegającym na naukowym uogólnieniu i usystematyzowaniu poszczególnych problemów. Ponadto mogła nią być praca projektowa, konstrukcyjna lub technologiczna. Co więcej, praca habilitacyjna mogła być (3) częścią pracy zespołowej, o ile wskazywała na indywidualny wkład kandydata w rozwój określonej dziedziny nauki lub dyscypliny naukowej.

Rozprawa habilitacyjna miała być napisana w języku polskim, w języku obcym wraz z jej streszczeniem w języku polskim wyłącznie za zgodą właściwej rady, i miała być przed wszczęciem przewodu habilitacyjnego opublikowana w całości. Rozprawa habilitacyjna mogła być też (co było nowym rozwiązaniem) opublikowana w skrócie pozwalającym na ocenę jej walorów naukowych. W tej drugiej sytuacji kandydat był obowiązany także do przedstawienia jej pełnego tekstu. Od wymagania publikacji rozprawy habilitacyjnej przed wszczęciem przewodu ustawa przewidywała dwa wyjątki. Pierwszy uzasadniało wyjątkowo zakwalifikowanie pracy do druku z powodu trudności technicznych lub finansowych poważnie wpływających na opóźnienie publikacji. Wyjątek drugi nakazywał odstąpienie od jej publikacji, gdy ta prowadziłaby do naruszenia tajemnicy państwowej. W obu przypadkach odstąpienie od obowiązku publikacji nie zwalniało kandydata od złożenie rozprawy habilitacyjnej w maszynopisie (co nie było nowym rozwiązaniem) w pięciu egzemplarzach (trzech w 1958 r.).

Rada (wydziału, naukowa) ${ }^{86}$ wraz z decyzją o wszczęciu przewodu habilitacyjnego powoływała co najmniej trzech recenzentów spośród pracowników naukowo-dydaktycznych lub naukowo-badawczych, z których co najmniej jeden miał posiadać tytuł naukowy profesora, a pozostali - stopień naukowy docenta (doktora habilitowanego ${ }^{87}$ ) z dziedziny

${ }^{86}$ Do ważności uchwał podejmowanych przez właściwą radę wymagano obecności co najmniej połowy ogólnej liczby osób uprawnionych do głosowania; uchwały zapadały w głosowaniu tajnym, większością dwóch trzecich głosów (od 1969 r. większością głosów). Zob. § 1 pkt 7 Rozporządzenia Rady Ministrów z dnia 3 XI 1969 r. zmieniające rozporządzenie w sprawie warunków i trybu przeprowadzania przewodów doktorskich i habilitacyjnych (Dz.U. Nr 31, poz. 253).

${ }^{87}$ Zob. $\$ 1$ pkt 8 rozporządzenia Rady Ministrów z dnia 3 XI 1969 r. zmieniającego rozporządzenie w sprawie warunków i trybu przeprowadzania przewodów doktorskich i habilitacyjnych. 
odpowiadającej tematowi rozprawy. Jednocześnie zastrzeżono, że co najmniej jeden $z$ recenzentów miał być powołany spoza grona pracowników instytucji, w której odbywał się przewód habilitacyjny. Bez względu na to, czy recenzent reprezentował instytucję, w której przewód habilitacyjny się odbywał, czy inną instytucję, przyjęcie obowiązków recenzenta $\mathrm{w}$ tym przewodzie sprowadzono do służbowego obowiązku pracowników naukowo-dydaktycznych i naukowo-badawczych (i to mocą rozporządzenia ${ }^{88}$, później zarządzenia ${ }^{89}$, a nie ustawy). Zwolnienie $z$ tego obowiązku było możliwe jedynie w uzasadnionych przypadkach (w obu aktach wykonawczych nieokreślonych). Recenzentem mógł być także profesor emerytowany. Recenzja, którą należało przedłożyć nie później niż w terminie trzech miesięcy po otrzymaniu rozprawy, miała zawierać szczegółowo uzasadnioną ocenę, po pierwsze - czy rozprawa habilitacyjna odpowiada warunkom ustawowym, i po drugie - czy cały dorobek kandydata uzasadnia nadanie stopnia naukowego docenta. To zastrzeżenie miało istotne znaczenie dla dalszych prac komisji powołanej przez właściwą radę (wydziału, naukową). Jej ocenie poddano bowiem sprawdzenie, czy recenzje odpowiadały stawianym im przez ustawę wymaganiom; jeśli nie, komisja mogła zarządzić ich uzupełnienie. To do komisji, a nie właściwej rady należało podjęcie decyzji o dopuszczeniu osoby ubiegającej się o stopień naukowy docenta do kolokwium habilitacyjnego. Jedynie jej decyzja negatywna w tym zakresie wymagała zatwierdzenia przez radę (wydziałową, naukową). Miało to ten skutek, że rozprawa habilitacyjna przedstawiona w tym przewodzie nie mogła być podstawą ubiegania się o nadanie stopnia naukowego docenta w innych instytucjach;

3. kolokwium habilitacyjne miało, przy zachowaniu formy dyskusji nad rozprawą habilitacyjna, wykazać wiedzę kandydata w zakresie aktualnej problematyki dyscypliny naukowej stanowiącej zakres habilitacji. Wobec przyjęcia rozwiązania, że praca habilitacyjna mogła być także częścią pracy zespołowej, prawo nie rozwiązywało kwestii przeprowadzenia kolokwium habilitacyjnego, gdy dotyczyło ono współautorów zespołowej pracy habilitacyjnej. Decyzję co do wyniku kolokwium

${ }^{88}$ Zob. § 31 ust. 1 rozporządzenia Rady Ministrów z dnia 8 II 1966 r. w sprawie warunków i trybu przeprowadzania przewodów doktorskich i habilitacyjnych.

${ }^{89}$ Zob. § 24 ust. 1 Zarządzenia Ministra Nauki i Szkolnictwa Wyższego z dnia 11 III 1986 r. w sprawie szczegółowych warunków i trybu przeprowadzania przewodów doktorskich i habilitacyjnych oraz zakresu egzaminów doktorskich i kolokwiów habilitacyjnych (M.P. Nr 11, poz. 74). 
podejmowała właściwa rada (wydziału, naukowa). Decyzja rady mogła być pozytywna lub negatywna. W sytuacji drugiej (negatywnej oceny kolokwium habilitacyjnego) rada wydziału (rada naukowa) mogła zezwolić na ponowne jego przeprowadzenie w ustalonym przez nią terminie. Sytuacja pierwsza z kolei prowadziła do:

4. powzięcia przez właściwą radę (wydziału, naukową) uchwały o nadaniu stopnia naukowego docenta/doktora habilitowanego. W brzmieniu pierwotnym ustawy uchwała rady wymagała zatwierdzenia ${ }^{90}$ przez: ministra sprawującego nadzór nad szkołą wyższą lub samodzielną placówką typu naukowo-badawczego, w której przewód habilitacyjny był przeprowadzony - po zasięgnięciu opinii Rady Głównej Szkolnictwa Wyższego (Rady Wyższego Szkolnictwa Wojskowego w zakresie nauk wojskowych); a gdy przewód habilitacyjny przeprowadzono w placówkach Akademii lub w instytutach naukowo-badawczych, przez sekretarza naukowego PAN - po zasięgnięciu opinii Głównej Komisji Kwalifikacyjnej działającej przy PAN. Od 1973 r. uchwałę o nadaniu stopnia naukowego doktora habilitowanego zatwierdzała $\mathrm{CKK}^{91}$. Tylko zatwierdzona uchwała o nadaniu stopnia naukowego docenta/ doktora habilitowanego dawała podstawę do przeprowadzenia:

5. uroczystej promocji habilitacyjnej i wręczenia na otwartym zebraniu dyplomu przez rektora wraz z dziekanem wydziału i promotorem - w szkołach wyższych; przewodniczącego rady naukowej wraz z kierownikiem placówki (instytutu) i promotorem - w placówkach naukowych PAN, samodzielnych placówkach typu naukowo-dydaktycznego oraz w instytutach naukowo-badawczych.

Od każdej decyzji powziętej przez radę (wydziału, naukową) $)^{92}$ odmawiającej: wszczęcia przewodu habilitacyjnego, dopuszczenia do

${ }^{90}$ Zob. art. 11 ust. 2 ustawy z 1965 r. Zgodnie z $\S 26$ ust. 3 rozporządzenia z 1966 r. w sprawie warunków i trybu przeprowadzania przewodów doktorskich i habilitacyjnych obligowało to właściwą radę do przekazania podjętej przez siebie uchwały w sprawie nadania stopnia naukowego docenta wraz $\mathrm{z}$ aktami postępowania habilitacyjnego, w terminie piętnastu dni, organowi uprawnionemu do jej zatwierdzenia.

${ }^{91}$ Artykuł 1 pkt 5 Ustawy z dnia 12 IV 1973 r. o zmianie przepisów dotyczących stopni naukowych i tytułów naukowych oraz organizacji instytutów naukowo-badawczych (Dz.U. Nr 12, poz. 89).

${ }^{92}$ Dla ważności jej podjęcia wymagano obecności co najmniej połowy ogólnej liczby osób uprawnionych do głosowania, posiadających tytuły naukowe profesora lub stopnie naukowe docenta (od 1969 r. także samodzielni pracownicy naukowo-badawczy oraz wchodzący w skład rady wydziału lub rady naukowej pracownicy ze stopniem naukowym doktora habilitowanego), jak również recenzenci i członkowie komisji powołanych przez właściwą radę. 
kolokwium habilitacyjnego lub nadania stopnia naukowego docenta/ doktora habilitowanego - kandydatowi służyło odwołanie, złożone za pośrednictwem danej rady. Organ właściwy ${ }^{93}$ po jego uwzględnieniu zwracał sprawę właściwej radzie (wydziału, naukowej) w celu ponownego rozpatrzenia lub przekazywał ją radzie innej instytucji uprawnionej do nadawania stopnia naukowego docenta.

\subsection{Przebieg przewodu habilitacyjnego w latach 1985-1990}

Zgodnie z ustawą z 1965 r. w brzmieniu nadanym w 1985 r. oraz zarządzeniem ministra nauki i szkolnictwa wyższego z dnia 11 marca $1986 \mathrm{r}$. przeprowadzenie wszystkich czynności przewodu habilitacyjnego powierzono radzie (wydziału, naukowej). Tylko niektóre z nich (ocena dorobku naukowego i rozprawy habilitacyjnej oraz przygotowanie na jej podstawie wniosku dotyczącego wszczęcia przewodu habilitacyjnego, powołania recenzentów dla przygotowania recenzji) właściwa rada mogła przekazać powołanej przez siebie komisji, złożonej z co najmniej pięciu osób (tu próg ten podwyższono) spośród swych członków ( $\mathrm{z}$ tytułem naukowym lub zajmujących stanowiska docenta i posiadających stopień naukowy doktora habilitowanego, przy założeniu, że większość członków komisji miała mieć tytuł naukowy). W uchwale powołującej komisję rada określała jej skład, wyznaczała przewodniczącego oraz zakres przekazanych komisji czynności. Przewodniczącemu komisji przysługiwały w zakresie przekazanych czynności uprawnienia dziekana (przewodniczącego rady naukowej). Członkowie komisji nie mogli łączyć tej funkcji z funkcją recenzenta.

${ }^{93}$ Organem rozstrzygającym odwołanie kandydata był: (1) w szkołach wyższych i samodzielnych placówkach typu naukowo-dydaktycznego - minister (kierownik urzędu centralnego) sprawujący nadzór nad szkołą wyższą lub placówką po zasięgnięciu opinii Rady Głównej Szkolnictwa Wyższego; (2) w placówkach naukowych PAN lub instytutach naukowo badawczych - sekretarz naukowy PAN po zasięgnięciu opinii Głównej Komisji Kwalifikacyjnej działającej przy PAN. Od 1973 r. rozstrzyganie odwołań od uchwał rad wydziału i rad naukowych (w tym także rad naukowych w instytutach typu naukowo-badawczego) leżało w gestii CKK (art. 19d ustawy z 1965 r. w brzmieniu nadanym ustawą z dnia 12 IV 1973 r.). W sprawach dotyczących przewodów habilitacyjnych w zakresie nauk wojskowych odwołania rozstrzygała Rada Wyższego Szkolnictwa Wojskowego (art. 15 pkt 3a ustawy z 1965 r. w brzmieniu nadanym art. 1 pkt 7 ustawy z dnia 12 IV 1973 r.). 
W odróżnieniu od rozwiązań z 1965 i 1966 r. rozbudowano (do siedmiu) czynności przewodu habilitacyjnego ${ }^{94}$ i objęto nimi:

1. wszczęcie przewodu habilitacyjnego na podstawie przedstawionej rozprawy habilitacyjnej oraz dokumentów dotyczących dorobku naukowego - w 1985 r. inaczej zdefiniowano warunki, jakim miała odpowiadać rozprawa habilitacyjna. Przy zachowaniu postanowienia przyjętego ustawą z 1965 r., zgodnie z którym rozprawa habilitacyjna miała stanowić poważny wkład kandydata w rozwój określonej dziedziny nauki lub dyscypliny naukowej, rozprawa miała stanowić (1) specjalnie napisane dzieło. Mógł nią być również (2) zamieszczony w czasopismach naukowych monotematyczny cykl samodzielnych oryginalnych publikacji stanowiących część dorobku naukowego kandydata, powstałego po uzyskaniu stopnia naukowego doktora (co było rozwiązaniem nowym). Warunek rozprawy habilitacyjnej spełniało (3) oryginalne i zrealizowane osiągnięcie projektowe, konstrukcyjne lub technologiczne, jeżeli łączyło się z rozwiązaniem istotnego problemu naukowego ${ }^{95}$, a także (4) część pracy zespołowej, jeżeli opracowanie wydzielonego zagadnienia było indywidualnym wkładem osoby ubiegającej się o nadanie stopnia naukowego doktora habilitowanego ${ }^{96}$.

Rozprawa habilitacyjna miała być opublikowana w całości lub w zasadniczej części. Warunek publikacji rozprawy był spełniony przez udostępnienie dzieła w inny sposób (bez jego wskazania) społeczności naukowej, a w szczególności specjalistom z danej dyscypliny. Rada wydziału (rada naukowa) mogła uchylić obowiązek przedłożenia rozprawy $\mathrm{w}$ formie publikacji ${ }^{97}$, jeżeli ta została przyjęta do druku.

${ }^{94}$ Czynności przewodu habilitacyjnego kończyły się uchwałami rady wydziału (rady naukowej). Te były ważne, jeżeli podjęto je w głosowaniu tajnym w obecności co najmniej połowy liczby osób uprawnionych do głosowania, a za przyjęciem uchwały wypowiedziała się więcej niż połowa osób uczestniczących w głosowaniu. Krąg osób uprawnionych do głosowania sprowadzał się do członków rady wydziału (rady naukowej) posiadających tytuł naukowy, docentów ze stopniem naukowym doktora habilitowanego lub doktora, recenzentów rozprawy habilitacyjnej oraz osób zaproszonych do uzupełnienia składu rady ( $\$ 1$ pkt 10 ustawy z dnia 25 VII 1985 r.).

${ }_{95}$ Rozprawa habilitacyjna miała zawierać dokładny opis pracy projektowej, konstrukcyjnej lub technologicznej, ze szczególnym udokumentowaniem rozwiązania problemu naukowego, stanowiącego podstawę pracy ( $\$ 18$ ust. 5 zarządzenia z dnia 11 III 1986 r.).

${ }^{96} \mathrm{~W}$ tym przypadku od wszystkich współautorów wymagano złożenia oświadczenia określającego ich role w opracowywaniu rozprawy i ich indywidualnego wkładu ( $\$ 9$ ust. 5 pkt 2 zarządzenia z dnia 11 III 1986 r.).

${ }^{97} \mathrm{~W}$ razie uchylenia przez właściwą radę obowiązku publikacji rozprawy habilitacyjnej na dziekanie (przewodniczącym rady naukowej) spoczywał obowiązek 
Jednakże wyłącznie opublikowanie rozprawy mogło stanowić warunek zatwierdzenia przez CKK uchwały rady (wydziału, naukowej) o nadaniu stopnia naukowego doktora habilitowanego. Obowiązkowi publikacji nie podlegały te rozprawy habilitacyjne, których przedmiot był objęty tajemnicą państwową lub (co było rozwiązaniem nowym) służbową. Tak jak w rozwiązaniach przyjętych w 1965 r., rozprawa habilitacyjna miała być napisana w języku polskim, przy czym właściwa rada mogła zezwolić na złożenie rozprawy napisanej w języku obcym, z obowiązkiem przedstawienia jej streszczenia w języku polskim;

2. powołanie co najmniej trzech recenzentów dla przygotowania recenzji - recenzentów powoływała rada (wydziału, naukowa) wraz z podjęciem uchwały o wszczęciu przewodu habilitacyjnego. Spośród nich co najmniej dwóch (próg ten podwyższono) miało posiadać tytuł naukowy, a pozostali stopień naukowy doktora habilitowanego z dziedziny odpowiadającej tematowi rozprawy habilitacyjnej i zajmujących stanowisko docenta. Co najmniej dwóch recenzentów należało powołać spoza grona pracowników i emerytów (byłych pracowników jednostki organizacyjnej przeprowadzającej przewód habilitacyjny) oraz spoza grona członków jej rady (co było także rozwiązaniem nowym);

3. ocenę dorobku naukowego i rozprawy habilitacyjnej - ocena w tym zakresie należała do właściwej rady, chyba że ta powołała stosowną komisję. Recenzja miała zawierać szczegółowo uzasadnioną ocenę spełnienia przez rozprawę habilitacyjną warunku jej stawianego przez ustawę oraz ocenę, czy dorobek naukowy kandydata uzasadnia nadanie mu stopnia naukowego doktora habilitowanego. $\mathrm{W}$ razie powołania komisji to na niej spoczywało sprawdzenie, czy recenzje odpowiadały powyższym wymaganiom, a w razie potrzeby także zarządzenie ich uzupełnienia i w drodze uchwały wystąpienie do rady (wydziału, naukowej) z wnioskiem o dopuszczenie lub niedopuszczenie habilitanta do kolokwium habilitacyjnego. W tej drugiej sytuacji (podjęcia przez radę uchwały o niedopuszczeniu do kolokwium habilitacyjnego) rozprawa habilitacyjna nie mogła stanowić podstawy ubiegania się o nadanie stopnia naukowego doktora habilitowanego w innych jednostkach organizacyjnych;

4. kolokwium habilitacyjne przeprowadzane podczas posiedzenia rady wydziału (rady naukowej) miało stanowić podstawę dyskusji nad

zawiadomienia o temacie rozprawy habilitacyjnej odpowiednich instytucji naukowych w celu umożliwienia zainteresowanym zapoznania się z jej treścią w siedzibie jednostki przeprowadzającej przewód, a także przekazania rozprawy do specjalistycznych instytucji naukowych i bibliotek. 
rozprawą habilitacyjną i dowieść wiedzy habilitanta w zakresie aktualnej problematyki dyscypliny naukowej stanowiącej przedmiot habilitacji. Jeżeli o uzyskanie stopnia naukowego doktora habilitowanego na podstawie rozprawy zespołowej ubiegała się w tej samej jednostce organizacyjnej więcej niż jedna osoba, kolokwium habilitacyjne należało przeprowadzić dla wszystkich habilitantów równocześnie (co było rozwiązaniem nowym);

5. ocenę kolokwium habilitacyjnego - ocena mogła być pozytywna lub negatywna. W sytuacji drugiej kolokwium habilitacyjne mogło być, za zgodą rady wydziału (rady naukowej), powtórzone w terminie nie krótszym niż sześć miesięcy i nie dłuższym niż jeden rok (nowe rozwiązanie). Pozytywna ocena kolokwium habilitacyjnego pozwalała na wygłoszenie przez habilitanta wykładu (co było powrotem do rozwiązania z 1958 r.);

6. wykład habilitacyjny habilitant mógł wygłosić na jeden z trzech tematów zgłoszonych radzie wydziału (radzie naukowej) do wyboru i przez nią wybrany. W szczególnie uzasadnionych przypadkach rada wydziału (rada naukowa) mogła osobę ubiegającą się o nadanie stopnia naukowego doktora habilitowanego, a niebędącą nauczycielem akademickim, zwolnić z przeprowadzenia wykładu habilitacyjnego. $W$ razie rozprawy zespołowej należało wysłuchać wykładów habilitacyjnych na tym samym posiedzeniu właściwej rady (i było to rozwiązanie po raz pierwszy wprowadzone). Po zakończeniu wykładu habilitacyjnego rada (wydziału, naukowa), biorąc pod uwagę oceny rozprawy habilitacyjnej i całego dorobku naukowego habilitanta oraz ocenę przebiegu kolokwium habilitacyjnego i wykładu habilitacyjnego, podejmowała:

7. uchwałę $w$ sprawie nadania lub odmowy nadania stopnia naukowego doktora habilitowanego w określonej dziedzinie nauki i dyscyplinie podstawowej ${ }^{98}$. W sytuacji pierwszej rada (wydziału, naukowa) uchwałę tę przekazywała (wraz z dokumentacją przewodu habilitacyjnego) w terminie czternastu dni od jej podjęcia CKK w celu zatwierdzenia. Po jej uprawomocnieniu następowała promocja habilitacyjna i wręczenie dyplomu, zgodnie z zasadami ustalonymi w szkole wyższej, placówce naukowej PAN, placówce typu naukowo-dydaktycznego lub instytucie naukowo-badawczym.

${ }^{98} \mathrm{~W}$ sprawach nadawania stopnia naukowego doktora habilitowanego uprawniono do głosowania członków rady wydziału (rady naukowej) posiadających tytuł naukowy i docentów ze stopniem naukowym doktora habilitowanego lub docenta, a także osoby zaproszone do uzupełnienia składu rady oraz recenzentów rozprawy habilitacyjnej. 
Każdej osobie ubiegającej się o nadanie stopnia naukowego doktora habilitowanego służyło odwołanie od uchwał rady (wydziału, naukowej) odmawiających: wszczęcia przewodu habilitacyjnego, dopuszczenia do kolokwium habilitacyjnego, przyjęcia kolokwium habilitacyjnego oraz nadania stopnia naukowego doktora habilitowanego. Odwołanie mógł kandydat wnieść do CKK, za pośrednictwem właściwej rady, w terminie miesiąca od dnia powiadomienia o treści uchwały. Natomiast obowiązkiem właściwej rady było przekazanie odwołania CKK wraz ze swoją opinią i aktami przewodu w terminie trzech miesięcy od dnia złożenia odwołania. CKK po rozpatrzeniu odwołania (w terminie nie dłuższym niż sześć miesięcy) mogła zaskarżoną uchwałę utrzymać w mocy albo ją uchylić. W sytuacji drugiej przekazywała sprawę do ponownego rozpatrzenia przez radę (wydziału, naukową) innej jednostki organizacyjnej. Zarazem o rozstrzygnięciu zawiadamiała osobę, która odwołanie wniosła, oraz zainteresowaną radę wydziału (radę naukową).

Uchwała o nadaniu stopnia naukowego doktora habilitowanego mogła być przez CKK zatwierdzona, niezatwierdzona lub unieważniona. W sytuacji pierwszej uchwała rady stawała się prawomocna $z$ chwilą jej zatwierdzenia przez CKK. W przypadku drugim (jej niezatwierdzenia) właściwa rada mogła w terminie trzech miesięcy od dnia doręczenia jej rozstrzygnięcia wystąpić do CKK z wnioskiem o ponowne rozpatrzenie sprawy. CKK przed podjęciem ostatecznego rozstrzygnięcia mogła umożliwić wymianę poglądów pomiędzy występującymi w przewodzie recenzentami pracy habilitacyjnej. $W$ razie przedłużenia terminu rozstrzygnięcia sprawy (ponad sześć miesięcy) była obowiązana do zawiadomienia zainteresowanej jednostki organizacyjnej o przyczynach zwłoki i do wskazania nowego terminu rozstrzygnięcia sprawy. Od niezatwierdzonej przez CKK uchwały danej rady (wydziału, naukowej) w sprawie nadania stopnia naukowego doktora habilitowanego ustawa nie przewidywała środków ochrony prawnej. Sytuacja trzecia, dotycząca unieważnienia uchwały o nadaniu stopnia doktora habilitowanego, zachodziła $w$ razie stwierdzenia, że rozprawa habilitacyjna naruszyła $\mathrm{w}$ istotny sposób autorskie dobra osobiste innych osób (co było nowym rozwiązaniem), chyba że od nadania tego stopnia naukowego upłynęło dziesięć lat. CKK uchwałę tę mogła unieważnić na wniosek: (1) osoby, której prawa autorskie zostały naruszone, lub jej następców prawnych; (2) rady wydziału (rady naukowej), która podjęła uchwałę o nadaniu stopnia naukowego doktora habilitowanego 
lub rady (wydziału, naukowej) jednostki organizacyjnej zatrudniającej osobę, której taki stopień naukowy nadano; (3) ministra nadzorującego (szkoły wyższe, instytuty naukowo-badawcze lub samodzielne placówki typu naukowo-dydaktycznego) albo sekretarza naukowego PAN. O wszczęciu postępowania w sprawie unieważnienia uchwały CKK zawiadamiała osobę, której zarzuty dotyczyły, oraz właściwą radę (wydziału, naukową). Osobie tej służyło prawo złożenia pisemnych wyjaśnień oraz przedstawienia dowodów na swoją obronę. O unieważnieniu uchwały CKK zawiadamiała tę radę (wydziału lub naukową), która stopień doktora habilitowanego nadała.

\section{Prawa instytucji do nadawania stopni naukowych i osób z niezakończonym przewodem habilitacyjnym w przepisach przejściowych}

Ustawa z 1965 r. jednoznacznie rozstrzygała sprawę dotychczasowego prawa szkół wyższych oraz innych ich jednostek organizacyjnych, placówek naukowych PAN, a także instytutów naukowo-badawczych do nadawania stopnia naukowego docenta/doktora habilitowanego oraz sytuację osób z niezakończonym przewodem habilitacyjnym do dnia jej wejścia w życie. Wobec powyższych instytucji zachowała nabyte przez nie na podstawie dotychczasowych przepisów uprawnienia, a zarazem przewidywała dalsze prowadzenie niezakończonych przewodów habilitacyjnych na podstawie tejże ustawy. Dla instytucji posiadających w dniu wejścia w życie ustawy uprawnienie do nadawania stopnia naukowego docenta, nabyte na mocy ustawy z 1958 r. o szkołach wyższych przewidującej wyższe standardy w zakresie poziomu środowiska naukowego warunkującego jego nabycie, przyjęte $\mathrm{w}$ roku 1965 rozwiązanie nie groziło utratą nabytych uprawnień (wymagania je warunkujące po $1965 \mathrm{r}$. były niższe). Z pewnością tłumaczyło to objęcie tylko niektórych instytucji ogłoszonymi w 1966 r. wykazami ustalającymi jednostki (placówki) uprawnione do nadawania stopnia naukowego docenta (art. 20).

Dla kandydatów do stopnia naukowego docenta/doktora habilitowanego rozwiązania przyjęte w roku 1965 bez wątpienia były znacznie korzystniejsze (art. 22) od tych przewidzianych ustawą z 1958 r. i wydanym na jej podstawie rozporządzeniem z 1959 r. Zgodnie z rozporządzeniem Rady Ministrów z dnia 8 lutego 1966 r. niezakończone 
do dnia jego wejścia w życie (tj. do dnia 6 marca 1966 r.) przewody habilitacyjne miały być prowadzone na jego podstawie ( $\$ 32)$. W ten sposób na wdrożeniu ustawy z 1965 r. zyskały zarówno instytucje uprawnione do nadawania stopni naukowych, jak i osoby zainteresowane ich nabyciem.

Podobnie jak ustawa z 1965 r. w brzmieniu obowiązującym przed 1985 r., także ustawa ją zmieniająca w roku 1985 normowała sytuację instytucji uprawnionych do nadawania stopnia naukowego doktora habilitowanego oraz osób, których przewody habilitacyjne nie zostały zakończone przed jej wejściem w życie. W odróżnieniu od nich kwestię tę określała inaczej. Stanowiła bowiem, że jednostki organizacyjne, które na podstawie dotychczasowych przepisów były uprawnione do nadawania stopnia naukowego doktora habilitowanego, uprawnienie to zachowywały przez okres dwóch lat od dnia wejścia w życie ustawy z 1985 r. Dopiero po upływie tego okresu stopień naukowy doktora habilitowanego mógł być nadawany na zasadach określonych ustawą zmieniająca. Tymczasem zgodnie z $\$ 25$ wydanego na jej podstawie zarządzenia ministra nauki i szkolnictwa wyższego z dnia 11 marca 1986 r. przewody habilitacyjne niezakończone do dnia jego wejścia w życie (tj. do dnia 15 kwietnia 1986 r.) miały być w dalszym ciągu prowadzone na podstawie tegoż zarządzenia (§ 25). Ten dualizm praw - instytucji i habilitantów - był tu bardzo wyraźny. Szkoły wyższe, samodzielne placówki typu naukowo-dydaktycznego, placówki naukowe PAN oraz instytuty naukowo-badawcze miały przez okres dwóch lat prawo do nadawania stopnia naukowego doktora habilitowanego w trybie i na warunkach mniej od nich wymagających w zakresie poziomu środowiska naukowego, te od 1985 r. przecież znacznie zaostrzono. Natomiast przed habilitantami z niezakończonym przed 1985 r. przewodem habilitacyjnym (czyli już wszczętym) postawiono warunki zaostrzone. Jakie ratio legis za takimi rozwiązaniami w obu okresach obowiązywania ustawy z 1965 r. przemawiało, trudno ustalić, zapewne można tu jedynie optować za względami pozaprawnymi.

Różna waga zakończonych pomyślnie dla kandydatów przewodów habilitacyjnych nie znajdowała odzwierciedlenia w ich awansach zawodowych. Osobie, która nabyła stopień naukowy docenta, mogło być powierzone stanowisko docenta etatowego (do 1968 r.). Tej zaś, której nadano stopień naukowy doktora habilitowanego - stanowisko 
docenta (od $1968 \mathrm{r} \cdot{ }^{99}$ ). Na stanowiska te mogły być również powołane osoby nieposiadające żadnego z tych stopni naukowych. Od 1982 r. na stanowisko docenta mogła być mianowana wyłącznie osoba posiadająca stopień naukowy doktora habilitowanego, i to ta, która wykazała się osiągnięciami w pracy dydaktycznej ${ }^{100}$.

\section{Podsumowanie}

Wyłączenie w pierwszych miesiącach 1965 r. spraw nadawania wyższego stopnia naukowego (docenta) z prawa szkolnictwa wyższego i wprowadzenie od 1968 r. stopnia naukowego doktora habilitowanego było zadaniem celowym i uzasadnionym. I w tym sensie miało ono bezwzględnie charakter przemian rewolucyjnych. Biorąc zaś pod rozwagę charakter i treść ówcześnie wprowadzonych rozwiązań prawnych, ich rewolucyjny charakter tracił na znaczeniu. $W$ istocie sprowadzał się do zastąpienia niemalże tych samych gałęzi nauki dziedzinami nauki i dyscyplinami naukowymi, w obrębie których mogły być nadawane wyższe stopnie naukowe, przy zmiennej w czasie liczbie dziedzin naukowych (z szesnastu w 1965 r. do dwudziestu w 1985 r., i ponownie szesnastu od 1986 r.) i różnej liczbie im przyporządkowanych dyscyplin naukowych (od 1986 r.). Korzystniejszym zmianom (do 1985 r.) poddano wymagania $\mathrm{w}$ zakresie poziomu środowiska naukowego i tzw. progu zatrudnienia, stawiane szkołom wyższym i placówkom typu naukowo-dydaktycznego oraz placówkom naukowym PAN i instytutom naukowo-badawczym. W roku 1966 próg ten stanowiło co najmniej dziesięciu pracowników $\mathrm{z}$ tytułami naukowymi lub ze stopniami naukowymi docenta, w tym co najmniej sześciu z tytułami profesora zwyczajnego lub profesora nadzwyczajnego; od 1985 r. co najmniej dwunastu pracowników z takimi tytułami naukowymi lub stopniami naukowymi. Uprawnieniem objęto tylko te dyscypliny nauki, które w danej jednostce organizacyjnej były reprezentowane przez co najmniej pięciu pracowników z tytułem

${ }^{99}$ Zob. art. 1 pkt 56 Ustawy z dnia 20 XII 1968 r. o zmianie ustawy o szkolnictwie wyższym (Dz.U. Nr 46, poz. 334), w którym skreślono słowo „etatowego” i w którym jednocześnie przyjęto, że "[s]topień naukowy doktora habilitowanego świadczy o posiadaniu dorobku naukowego wymaganego do zajęcia stanowiska docenta".

${ }^{100}$ Artykuł 135 Ustawy z dnia 4 V 1982 r. o szkolnictwie wyższym (Dz.U. Nr 14, poz. 113). 
naukowym lub ze stopniem naukowym doktora habilitowanego. Zarazem wymagano, by wśród członków rady zatrudnionych w jednostce organizacyjnej znajdował się co najmniej jeden pracownik z tytułem naukowym lub stopniem naukowym doktora habilitowanego zajmujący stanowisko docenta, reprezentujący specjalność odpowiadającą tematowi rozprawy habilitacyjnej.

To, co w 1965 r. było niezmiernie ważne, bez wątpienia dotyczyło uporządkowania wykazów jednostek organizacyjnych uprawnionych do nadawania stopnia naukowego docenta przez objęcie nimi, prawem powszechnie obowiązującym, także placówek naukowych PAN i instytutów naukowo-badawczych. Zmieniały się natomiast organy upoważnione ustawą do ustalania wykazów, poczynając od przewodniczącego Komitetu Nauki i Techniki działającego w uzgodnieniu z ministrem szkolnictwa wyższego i z sekretarzem naukowym PAN, poprzez ministra nauki, szkolnictwa wyższego i techniki działającego z własnej inicjatywy lub na wniosek zainteresowanego ministra w porozumieniu z sekretariatem naukowym PAN i po zasięgnięciu opinii CKK, ministra nauki i szkolnictwa wyższego, a kończąc na ministrze edukacji narodowej.

Innej ocenie podlegają natomiast warunki i tryb przebiegu przewodów habilitacyjnych. Wprawdzie w obu okresach (lata 1965-1985 i 1986-1990) prawne uregulowania zgodnie formułowały przebieg przewodu habilitacyjnego przez wymienienie kolejno następujących po sobie czynności, nie były to rozwiązania jednolite. Różnice sprowadzały się do: (1) liczby oraz rodzaju czynności objętych przewodem habilitacyjnym i ich treści; (2) właściwości organów je przyjmujących w drodze uchwały; (3) odwołań od uchwał negatywnych rozstrzygnięć danej rady; (4) organów właściwych do zatwierdzania, niezatwierdzania, unieważniania uchwał rady (wydziału, naukowej) w sprawie nadania stopnia naukowego. To, co w obu badanych okresach było rozwiązaniem nowym, sprowadzało się przede wszystkim do: (1) rozszerzenia formuły rozprawy habilitacyjnej wychodzacej poza ramy zwartego monograficznego opracowania; (2) odstapienia w latach 1965-1985 od obowiązku wygłoszenia przez kandydata do stopnia naukowego wykładu habilitacyjnego; (3) od 1973 r. zatwierdzania przez Centralna Komisję Kwalifikacyjną uchwały właściwej rady (wydziału, naukowej) o nadaniu stopnia naukowego doktora habilitowanego; (4) od 1985 r. unieważniania uchwał rady wydziału (rady naukowej) o nadaniu stopnia doktora habilitowanego $\mathrm{w}$ razie stwierdzenia naruszenia rozprawą habilitacyjną w sposób istotny autorskiego dobra osobistego innych osób. 


\section{HABILITATION DEGREES IN THE POLISH PEOPLE'S REPUBLIC. PART 2. REQUIREMENTS AND CONDITIONS OF HABILITATION PROCEEDINGS UNDER THE LAW ON ACADEMIC DEGREES AND TITLES}

\section{S u m mary}

Habilitation proceedings ending with a conferral of an academic degree were first introduced in the Polish People's Republic by virtue of the Act on higher education of 1958. The academic title of docent, which the Act also provided for, was later endorsed by the Act of 1965 on academic titles and academic degrees. Another academic degree of 'habilitated doctor' (doktor habilitowany) functioned from 1968 and continued through subsequent legislative acts in force until 1990 as well as through the years after later reforms. The changes in higher education implemented in 1965-1990 were not final and continued to be modified in the following areas: (1) the branches and science and disciplines in which the academic degrees of docent or doktor habilitowany could be conferred; (2) the requirements which institutions (establishments of higher education, research units of the Polish Academy of Sciences and other research entities) had to fulfil before earning the rights to confer the academic degrees referred to above; (3) establishment of the lists of institutions entitled to confer these academic degrees. The solutions then adopted were by no means triggered by the intention to replace the academic degree of docent with a degree of doktor habilitowany. On the contrary, the majority of changes, of which those happening after 1985 were even more politically biased, did not reflect any legal need but aimed at restricting the autonomy of schools of higher education in the scope of conferring academic degrees.

This tendency extended to the conditions of commencing habilitation proceedings and the very course of the proceedings. As of 1985 one of the requirements of the key factors qualifying successful candidates was an 'impeccable civic attitude.' After 1985, most of the activities which had been till then conducted by committees appointed Faculty councils, were to be taken up by the relevant councils, although the latter were allowed to appoint from time to time committees to perform some of the activities related to habilitation proceedings. The Act of 1965 abandoned the requirement of the candidate's habilitation lecture, re-established in 1985.

Keywords: academic degree of docent - academic degree of doktor habilitowany requirements before candidates in habilitation proceedings - requirements before institutions applying for the right to confer docent and doktor habilitowany degrees relevant bodies 